\section{Pacific Northwest}

National Laboratory

Operated by Battelle for the

U.S. Department of Energy

\title{
Program Plan for Acquiring and Examining Naturally Aged Materials and Components for Nuclear Reactors
}

\author{
A.B. Johnson, Jr. \\ S.K. Sundaram \\ F.A. Garner
}

December 2001

Prepared for the U.S. Department of Energy under Contract DE-AC06-76RL01830 


\title{
DISCLAIMER
}

This report was prepared as an account of work sponsored by an agency of the United States Government. Neither the United States Government nor any agency thereof, nor Battelle Memorial Institute, nor any of their employees, makes any warranty, express or implied, or assumes any legal liability or responsibility for the accuracy, completeness, or usefulness of any information, apparatus, product, or process disclosed, or represents that its use would not infringe privately owned rights. Reference herein to any specific commercial product, process, or service by trade name, trademark, manufacturer, or otherwise does not necessarily constitute or imply its endorsement, recommendation, or favoring by the United States Government or any agency thereof, or Battelle Memorial Institute. The views and opinions of authors expressed herein do not necessarily state or reflect those of the United States Government or any agency thereof.

\author{
PACIFIC NORTHWEST NATIONAL LABORATORY \\ operated by \\ BATTELLE \\ for the \\ UNITED STATES DEPARTMENT OF ENERGY \\ under Contract DE-AC06-76RL01830
}

This document was printed on recycled paper. 


\section{Program Plan for Acquiring and Examining Naturally Aged Materials and Components from Nuclear Reactors}
A. B. Johnson, Jr.
S. K. Sundaram
F. A. Garner

December 2001

Prepared for

the U.S. Department of Energy

under Contract DE-AC06-76RL01830

Pacific Northwest National Laboratory

Richland, Washington 99352 


\section{Summary}

The basis for this project is the need to maintain awareness of the conditions of components, materials, and structures (CMSs) in nuclear power plants as their service periods increase The need involves two important focuses: first, to systematically confirm satisfactory behavior of plant safety-related CMSs and to effectively understand and mitigate, as they emerge, new phenomena that could degrade safety margins. Second, to further validate the margins that were originally designed into the plants, for example, radiation effects on reactor pressure vessel embrittlement.

Sustained awareness of the condition of NPP equipment involves the need for selective access to naturally-aged CMSs. The motivation for this project is to provide a systematic, ordered approach to identify and coordinate acquisition of candidate CMs that are recognized as important to resolve key issues. The first need is to develop a broad consensus regarding the priority candidates that need to be accessed. The second need is to identify which plants, either operating or shutdown, have candidates that could be available on a timely basis. A timely, coordinated approach can mitigate problems that have sometimes arisen when potentially valuable candidates were not recognized in time to arrange consensus and funding to access, derive, and apply the information represented by the candidates. Another value of the coordinated approach is to avoid accessing CMSs that are of marginal value and end up not being utilized.

Sponsored by the Nuclear Plant Optimization (NEPO) Program, this project is administered jointly by the U.S. Department of Energy (DOE) and the Electric Power Research Institute (EPRI). A leading NEPO objective is to implement technology development that will prevent, detect, or repair degradation that results from long-term operation and exposure of materials to harsh environmental conditions in Nuclear Power Plants (NPPs). The scope of this project is to develop an integrated plan to identify NPP aging issues that are advanced by effectively investigating the condition of naturally aged NPP CMSs. From NPP CMSs identified in the plan, specific candidates will be identified that are considered valuable for examination. The examinations could be in situ at operating or shutdown reactors or they could be conducted on CMs removed from operating or shutdown reactors.

The approach to develop the plan was designed by a steering committee comprised of staff from the US Department of Energy (USDOE), the Electric Power Research Institute (EPRI), and the Pacific Northwest National Laboratory (PNNL). The Plan includes the following elements:

- A preliminary list of candidate CMSs, based on interactions with NPP staff, research organizations, and regulatory staff. However, the list must be subject to additions and deletions as a broader consensus is applied and as issues are resolved or as new issues emerge

- Perspectives and matrices that provide the bases for selection of the candidates and a summary of issues and status for each leading candidate (secondary candidates are presented, prompted by discussions with staffs from various organizations)

- Summaries of lessons learned from prior or ongoing plant decommissionings that provide guidance to facilitate more effective approaches to future initiatives 
- A list of US NPPs that are in shutdown status, for consideration in identifying candidate CMSs

- Reviews of US and selected foreign programs addressing assessment of age-related degradation of NPP safety-related equipment.

Aging management in NPPs is systematically addressed through specific aging management programs (AMPs) that have regulatory approval during the 40-year license period and in the license renewal period. Through systematic application of the AMPs, plant operators satisfy the regulatory requirements for safe operation. While acknowledging that the basis for effective aging management has been established, the need continues for vigilance and investigation of age-related phenomena as they emerge (for example, the Summer nozzle defect). Also, understanding of some aging issues is sufficient to facilitate safe operation but may impose considerable conservatism. Benchmarking existing models by examination of materials that have requisite service times offers a potentially valuable approach to address some of the conservatisms. Finally, impacts of corrosion and other aging issues in US NPPs have imposed diminished capacity factors, resulted in numerous major component replacements exceeding $\$ 100$ million at numerous plants, and caused shutdown of several plants due to issues related to reactor pressure vessel embrittlement and SG replacement.

The preliminary primary list of CMS candidates is:

- Reactor Pressure Vessel Wall and Nozzle Specimens

- Steam Generator Tubes and Shells

- Concrete Structures (Other than Containments)

- BWR Vessel Internals

- PWR Vessel Internals

- Thermally Aged Cast Stainless Steel Pipe

- Buried Piping/Tanks

- Flat Bottom Tanks.

There have been proposals to investigate selected CSs that may be subject to degradation in seismic events, including buried pipes/tanks and flat bottom tanks. Aging issues addressed in this project are expected to be relevant to NPP operation in the period of the original licenses and in the period of license renewal (LR).

The preliminary list of aging materials/components has emerged from discussions with staff from the USDOE, EPRI, the Nuclear Regulatory Commission (NRC), the International Atomic Energy Agency (IAEA), research laboratories, and from a review of literature addressing NPP aging studies. The plan is intended to be a living document that will be updated as further need for aging information is identified.

Candidate priority CMSs will be analyzed in detail that provides NEPO or other funding organizations with a basis to issue requests for proposal (RFPs) to address aging issues that are broadly regarded as important to support the basis for continuing safe operation of NPPs. 


\section{Acronyms and Abbreviations}

2D and $3 \mathrm{D}$

AMP

ANL

ASME

BRP

BWR/PWR

BWRVIP

CASS

CFR

CIR

$\mathrm{CM}$

CS

CMS

DECON

DOE

dpa

ENTOMB

EPRI

GALL

HTGR

I\&C

IAEA

IASCC

IGSCC

ISFSI

ITG

JAPEIC

JOBB

LER

LR

LRA

LWR

MA

MOU

MRP

NDE

NEI

NEPO

NERI

NPAR

NPP

NPS

NPRDS 2-dimensional and 3-dimensional

Aging Management Program

Argonne National Laboratory

American Society of Mechanical Engineers

Big Rock Point (BWR)

boiling water reactor/pressurized water reactor

BWR Vessel and Internals Project

cast austenitic stainless steel

Code of Federal Regulations

Cooperative Industry Research

component/material

component/structure

component, material, structure

portions of facility decontaminated to a defined level

Department of Energy

displacements per atom

decommissioning method

Electric Power Research Institute

generic aging lessons learned

high temperature gas reactor

Instrumentation and control

International Atomic Energy Agency

irradiation-assisted stress corrosion cracking

intergranular stress corrosion cracking

independent spent fuel storage installation

Issues Task Group

Japan Power Engineering Corporation

Joint Owners' Baffle Bolt (program)

licensee event report

license renewal

license renewal spplications

light water reactor

mill annealed

Memorandum of Understanding

Materials Research Program

non-destructive evaluation

Nuclear Energy Institute

Nuclear Energy Plant Optimization (program)

Nuclear Energy Research Initiative

Nuclear Plant Aging Research (program)

nuclear power plant

normal pipe size

Nuclear Plant Reliability Data System 


$\begin{array}{ll}\text { NRC } & \text { Nuclear Regulatory Commission } \\ \text { NUPEC } & \text { Nuclear Power Engineering Corporation } \\ \text { OTSG } & \text { once-thru steam generator } \\ \text { PNNL } & \text { Pacific Northwest National Laboratory } \\ \text { PTS } & \text { pressurized thermal shock } \\ \text { PWR } & \text { pressurized water reactor } \\ \text { PWSCC } & \text { pressurized water stress corrosion cracking } \\ \text { R\&D } & \text { research and development } \\ \text { RFP } & \text { request for proposal } \\ \text { RPV } & \text { reactor pressure vessel } \\ \text { RSG } & \text { re-entrant steam generator } \\ \text { SAFSTOR } & \text { facility kept in safe and stable condition after permanent shutdown } \\ \text { SCC } & \text { stress corrosion cracking } \\ \text { SEN } & \text { sensitized } \\ \text { SER } & \text { safety evaluation report } \\ \text { SG } & \text { steam generator } \\ \text { SRP-LR } & \text { Standard Review Plan - License Renewal } \\ \text { SS } & \text { stainless steel } \\ \text { SSC } & \text { system, structure, and component } \\ \text { TLAA } & \text { time-limited aging analysis } \\ \text { TT } & \text { thermally treated } \\ \text { WIM } & \text { welding technology of irradiated materials } \\ \text { VVER } & \text { Soviet-designed PWR-type NPP }\end{array}$




\section{Acknowledgments}

The authors are grateful to John Carey, Avtar Singh, and George Sliter of EPRI and Todd Allen of the Department of Energy for guidance in development of the basis for the program plan; to staff from several organization, notably, Greg Robison of Duke Power, Tim Griesbach, ATI Consulting, Al Mcilree and Raj Pathania, EPRI, Frank Gregor, LCM Technology, Jit Vora, and Joe Muscara of NRC, Bill Shack and Vik Shah of Argonne National Laboratory, J. I. Braverman and Robert Lofaro of Brookhaven National Laboratory, Randy Nanstad of Oak Ridge National Laboratory, Steve Doctor, James Dukelow, Don Jarrell, and Fred Simonen of PNNL, Spencer Bush, consultant, and Jaroslav Pachner of IAEA for discussions regarding aging issues for NPP safety-related materials/components. 


\section{Contents}

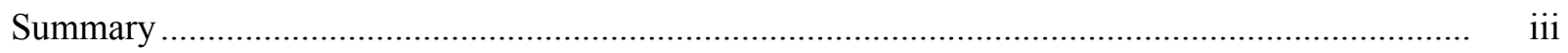

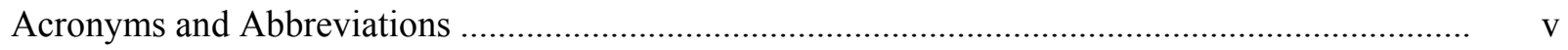

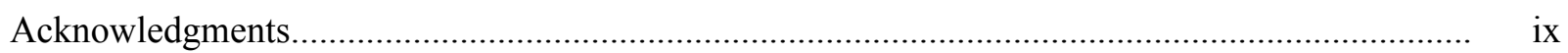

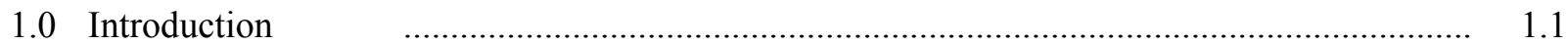

2.0 Development of the Plan for Assessing Naturally Aged Nuclear Power Plant Components,

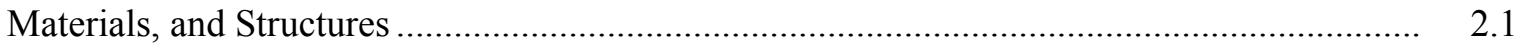

3.0 Preliminary Primary and Secondary Candidate Naturally Aged Materials, Components, and Structures for Access and Examination .............................................................................. 3.1

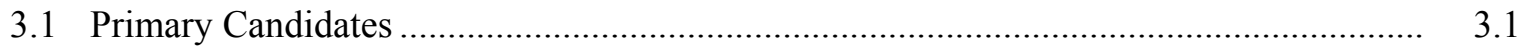

3.2 Perspectives and Matrices for Primary Candidates ...................................................... 3.1

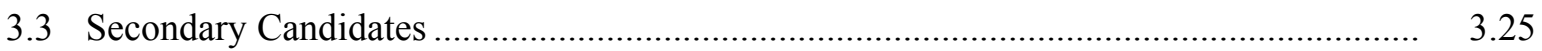

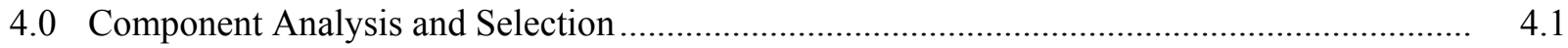

4.1 Criteria for Selection of Candidate Materials/Components ......................................... 4.1

4.2 Options for Investigation of Naturally Aged Materials/Components ............................ 4.1

4.3 Aging Management in License Renewal............................................................. 4.2

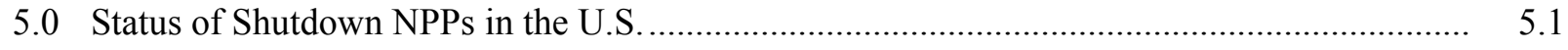

6.0 Prospects to Obtain Materials/Components From Foreign reactors ........................................

7.0 Major Problems Involving Examination of Naturally-Aged NPP Components...................... 7.1

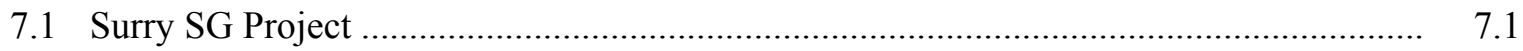

7.2 Shippingport Reactor Decommissioning............................................................ 7.1

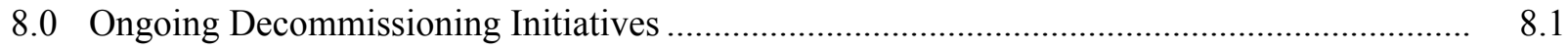

8.1 Big Rock Point - Status and Lessons Learned .................................................... 8.1 
9.0 Review of Aging/License Renewal Initiatives and Literature ......................................... 9.1

9.1 Electric Power Research Institute Initiatives............................................................ 9.1

9.2 International Atomic Energy Agency (IAEA) Initiatives ........................................ 9.2

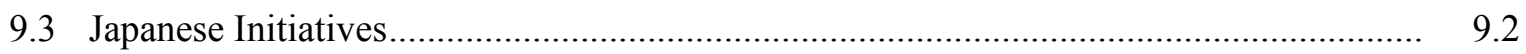

9.4 Other International Programs to Investigate Aging Issues........................................ 9.3

9.5 U.S. Department of Energy Initiatives ….............................................................. 9.4

9.6 U.S. Nuclear Regulatory Commission Initiatives ..................................................... 9.5

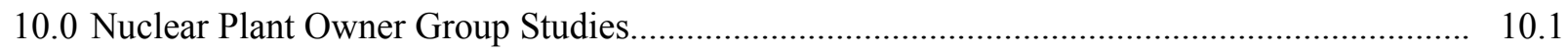

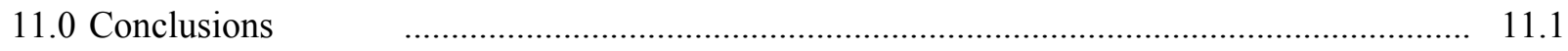

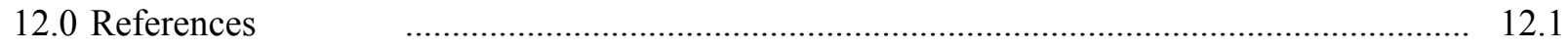

\section{Tables}

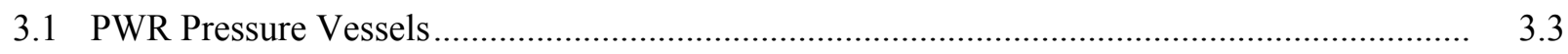

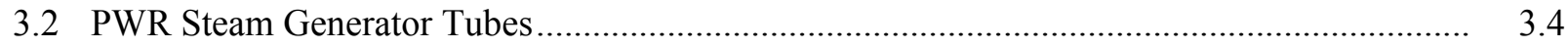

3.3 Other Seismic Category I Concrete Structures .......................................................... 3.7

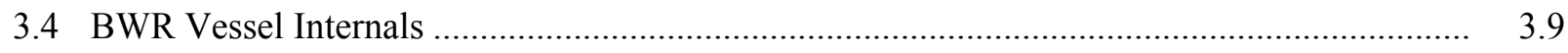

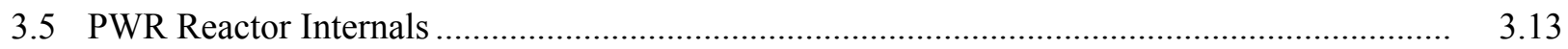

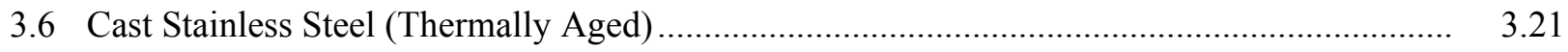

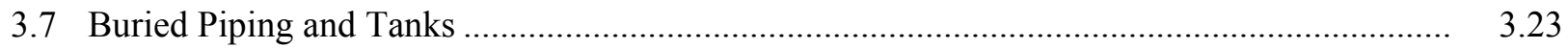

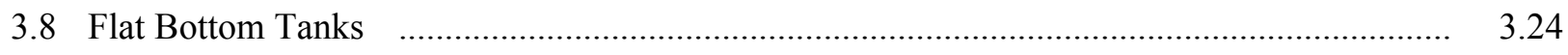

6.1 Permanently Shutdown Plants (Ref. Hickey et al. 2001) .................................................. 6.2 


\subsection{Introduction}

This project is sponsored by the Nuclear Energy Plant Optimization (NEPO) Program, administered jointly by the Department of Energy (DOE) and the Electric Power Research Institute (EPRI). It involves developing a program plan that identifies naturally aged nuclear power plant (NPP) components, materials, and structures (CMSs) that are candidates for examination to address issues relevant to aging degradation and aging management as plant operating periods increase. The plan forms the basis for a systematic, coordinated approach to identify candidates for examination on a timely basis that facilitates development of a consensus regarding the relevance of the candidate and provides ample lead time to identify funding sources. A matrix format provides a systematic evaluation of issues relevant to the candidate and identifies similar initiatives that are planned or underway to provide for integration and avoid duplication. The plan is intended to be a living document that will be updated as improved understanding of aging issues develops or as new aging issues emerge.

Commercial NPPs have operated in the U.S. for more than 40 years. Assurance of safe NPP operation as service times increase has been the subject of systematic investigations by the U.S. Nuclear Regulatory Commission (NRC), by the DOE, and by the nuclear power industry. Motivations to understand and effectively manage aging in NPPs have two related time frames:

- the period of 40-year licenses

- the period of license renewal (LR) (those plants approved by the NRC for up to 20 years of additional operation).

Symptomatic of the impact of aging phenomena on NPPs, corrosion diminished the capacity factors of U.S. plants by an average of 5 percent during the 1990s (EPRI 1997). In that period, repairs averaged more than $\$ 1$ billion per year across the nuclear power industry. At least 15 plants have invested more than $\$ 100$ million each in replacement of major components. Several NPPs were permanently shut down due to issues related to reactor pressure vessel embrittlement and SG replacement. Recent investigations have identified phenomena, such as void swelling of reactor core materials that need improved evaluation. Experience in essentially all technologies indicates that sustained surveillance is required to identify deleterious phenomena that emerge and to counteract them before they impose safety and economic penalties.

These realities provide incentive to conduct systematic assessments of materials issues that will benefit from access to naturally aged CMSs. The important outcome of these assessments will be improved understanding and management of aging in NPPs.

The Plan includes the following elements:

- A preliminary list of candidate CMSs, based on interactions with NPP staff, research organizations, and regulatory staff. However, the list must be subject to additions and deletions as a broader consensus is applied and as issues are resolved or as new issues emerge 
- Perspectives and matrices that provide the bases for selection of the priority candidates and a summary of issues and status for each leading candidate (secondary candidates are presented, prompted by discussions with staffs from various organizations)

- Summaries of lessons learned from prior or ongoing plant decommissionings that provide guidance to facilitate more effective approaches to future initiatives

- A list of US NPPs that are in shutdown status, for consideration in identifying candidate CMSs

- Reviews of US and selected foreign programs addressing assessment of age-related degradation of NPP safety-related equipment.

Aging terminology defined here is based on the reference: Common Aging Terminology. A Glossary for Understanding and Managing the Aging of Nuclear Power Plant Systems, Structures, and Components (SSC), published by the Electric Power Research Institute, Palo Alto, California (EPRI 1993).

Aging: (noun) general process where characteristics of an SSC gradually change with time or use.

Natural aging: aging of an SSC that occurs under pre-service and service conditions, including error-induced conditions.

Error-induced conditions: adverse pre-service or service conditions produced by design, fabrication, installation, operation, or maintenance errors.

Aging degradation: aging effects that could impair the ability of an SSC to function within acceptance criteria.

Examples: reduction in diameter from the wear of a rotating shaft, loss in material strength from fatigue or thermal aging, swelling of potting compounds, and loss of dielectric strength or cracking of insulation.

Aging effects: net changes in characteristics of an SSC that occur with time or use and are due to aging mechanisms

Examples: negative effects - see aging degradation; positive effects - increase in concrete strength from curing; reduction of vibration from wear-in of rotating machinery.

Aging mechanism: specific process that gradually changes characteristics of an SSC with time or use

Examples: curing, wear, fatigue, creep, erosion, microbial fouling, corrosion, embrittlement, and chemical or biological reactions.

Artificial aging: simulation of natural aging effects on SSCs by application of stressors representing plant pre-service and service conditions, but perhaps different in intensity, duration, and manner of application. 


\subsection{Development of the Plan for Assessing Naturally Aged Nuclear Power Plant Components, Materials, and Structures}

A steering group comprised of staff from the Electric Power Research Institute (EPRI), Pacific Northwest National Laboratory (PNNL), and the U.S. Department of Energy formulated the approach for this project. The group devised a matrix format to focus on important elements that identify key aging characteristics of a given CMS, evaluate what further effort is needed, and what related initiatives are already underway. The strategy adopted was to identify a list of experts and to derive input to the priority list of CMSs via telephone and email contacts and through some direct discussions with the experts. Important input also was obtained from regulatory, industry, and laboratory publications.

There were divergent views on CMS priorities. Some candidates were recommended which, on balance, did not make the first cut. However, a list of secondary candidates is included to reflect the range of CMSs considered. 


\subsection{Preliminary Primary and Secondary Candidate Naturally Aged Materials, Components, and Structures for Access and Examination}

Numerous candidates were put forward. It seemed useful to expose the complete list, but it is clear that resources will not be available in the near term to address all the candidates. Therefore, the candidates were divided into primary and secondary lists. The primary candidates were analyzed in the format of matrices that identify CMS characteristics, aging issues, information needed, and related initiatives that that are underway. The basis for interest in secondary candidates is briefly addressed.

\subsection{Primary Candidates}

The candidates presented here address NPP aging issues that will benefit from investigation of naturally aged CMSs, either involving assessments in operating plants, in shut down plants, or on CMs removed from operating or shutdown plants. The primary list is indicated below, followed by perspectives and matrices for each candidate. Some matrices were developed to advanced stages. Others will benefit from additional input from experts with detailed knowledge of the topic.

- Reactor Pressure Vessel Wall and Nozzle Specimens

- Steam Generator Tubes and Shells

- Concrete Structures (Other than Containments)

- BWR Vessel Internals

- PWR Vessel Internals

- Thermally Aged Cast Stainless Steel Pipe

- Buried Piping/Tanks

- Flat Bottom Tanks

\subsection{Perspectives and Matrices for Primary Candidates}

This section provides perspectives on reasons for placing candidates on the primary list. The section also includes a matrix format for each candidate to identify key information, aging issues, information needed, and related initiatives that are underway.

\section{Perspectives: Reactor Pressure Vessels (RPVs)}

Assuring the integrity of Nuclear Power Plant (NPP) RPVs continues to have high regulatory and industry priority. Technical issues include prediction of radiation embrittlement of RPV steels; fracture behavior of RPV steels; weld flaw density and distribution; and neutron dosimetry. The RPV must resist operational and accident loadings. Technical bases are still being advanced to evaluate vessel integrity for setting pressure-temperature limits; for evaluating cracks that may be detected during in-service inspections, and for evaluating pressurized thermal shock. 
Through-wall attenuation of neutron-induced damage is accepted by the Nuclear Regulatory Commission (NRC) as an open issue. Calculation of neutron attenuation effects is defined in Regulatory Guide 1.99, Rev. 2, based on neutronic transport calculations, backed by data from surveillance specimens irradiated with the RPV and removed periodically for testing. For license renewal, RPVs are subject to Time Limited Aging Analysis (TLAA) to assess the state of vessel embrittlement. However, models would benefit from benchmarking data from direct measurement of embrittlement profiles across full sections removed from walls of retired RPVs. A motivation for benchmarking is to determine the level of conservatism that exists in the calculations. Investigators comparing service characteristics of U.S. and Russian RPVs concluded "There is continuing insufficiency of underlying relevant mechanistic knowledge on irradiation damage and apparently an insufficiency of data to fully evaluate the irradiation response.” (Davies 1997)

Cost is a major challenge in obtaining, evaluating, and disposing of through-wall trepan samples from a decommissioned RPV. Multisponsor programs have been developed to accommodate major initiatives, for example, examination of a degraded Surry steam generator (SG), Section 7.1. Equipment was designed to drill a specimen from the wall of the Shippingport RPV. Access to the RPV wall sample was facilitated by the fact that the Shippingport RPV was to be filled with grout prior to shipment. However, the drilling equipment was not constructed in time to complete the sampling. If the RPV wall serves as the primary containment for radioactivity during shipment and burial, penetrations through the wall would need to be repaired to the satisfaction of those with environmental oversight. Obtaining a specimen from the Trojan RPV after it was transported to the burial site was considered but was not pursued due to concerns that there would be resistance from environmental authorities. Currently, the San Onofre NPP Unit 1 is being decommissioned. Access to specimens from the RPV wall is being explored. Table 3.1 summarizes aging issues and needs for naturally aged specimens from RPV walls.

\section{Perspectives: PWR Steam Generators}

Steam generator problems are the second highest contributors to lost power generation in US NPPs. Numerous SGs have been removed from service. Tubes in replacement SGs involve materials demonstrated in laboratory tests to have improved resistance to aging mechanisms that have plagued first generation tube materials. Meanwhile, remaining first-generation tube materials need to function with a high degree of safety. This requires a satisfactory basis to detect degraded conditions in the tubes. Crack morphologies seem to change with time in service, involving crack networks, connected by ligaments. Knowledge of how these cracks behave in normal operation and in accident scenarios is needed. Nondestructive testing equipment needs to be calibrated to accurately detect and size cracks. Cracks formed in the laboratory provide one source of calibration. However, there is a further need to benchmark nondestructive evaluation (NDE) detection and sizing against crack structures formed in service. While there is available an inventory of degraded tubes removed from various PWR SGs, there is a motivation to periodically evaluate recent crack morphologies by removal of tubes from operating or recently shutdown plants.

The GALL report (NUREG-1801) indicates need for further evaluation of SG tubes, repair sleeves, and plugs. Effectiveness of a proposed aging management program is to be evaluated. Table 3.2 summarizes aging issues and needs for naturally aged SG tubes. Shells of SGs also have degraded, including weld cracking. 
Table 3.1. PWR Pressure Vessels

\begin{tabular}{|c|c|c|c|c|c|c|c|}
\hline Components & Materials & $\begin{array}{c}\text { Aging } \\
\text { Mechanisms }\end{array}$ & $\begin{array}{l}\text { Aging } \\
\text { Effects }\end{array}$ & Aging Issues & $\begin{array}{l}\text { Information } \\
\text { Needed }\end{array}$ & $\begin{array}{c}\text { Information/Samples } \\
\text { Availability }\end{array}$ & $\begin{array}{c}\text { Current } \\
\text { Resources and } \\
\text { Level of Efforts }\end{array}$ \\
\hline $\begin{array}{l}\text { Beltline region, } \\
\text { shell, }\end{array}$ & $\begin{array}{l}\text { SA533B-1 } \\
\text { SA508; SA336; }\end{array}$ & $\begin{array}{l}\text { Radiation } \\
\text { embrittlement; }\end{array}$ & $\begin{array}{l}\text { Loss of } \\
\text { fracture } \\
\text { toughness; } \\
\text { unstable cracks }\end{array}$ & $\begin{array}{l}\text { Challenge to } \\
\text { RPV integrity } \\
\text { i.e., PTS, } \\
\text { LTOP }\end{array}$ & $\begin{array}{l}\text { Embrittlement } \\
\text { profile for RPV wall } \\
\text { material } \\
\text { (benchmarking) }\end{array}$ & $\begin{array}{l}\text { Access to specimens } \\
\text { removed from RPV after } \\
\text { service e.g. SONGS PWR }\end{array}$ & $\begin{array}{l}\text { Interest but no } \\
\text { current } \\
\text { commitment }\end{array}$ \\
\hline Cladding, pads & Stainless steel & $\begin{array}{l}\text { Environmental } \\
\text { fatigue, SCC }\end{array}$ & $\begin{array}{l}\text { Crack } \\
\text { initiation and } \\
\text { growth }\end{array}$ & $\begin{array}{l}\text { Crack } \\
\text { propagation } \\
\text { from cladding } \\
\text { into base } \\
\text { metal; } \\
\text { Exposure of } \\
\text { base metal to } \\
\text { coolant }\end{array}$ & $\begin{array}{l}\text { Inspection to } \\
\text { characterize crack } \\
\text { propagation }\end{array}$ & $\begin{array}{l}\text { Access to specimens } \\
\text { removed from RPV after } \\
\text { service e.g. SONGS PWR }\end{array}$ & $\begin{array}{l}\text { Interest but no } \\
\text { current } \\
\text { commitment }\end{array}$ \\
\hline $\begin{array}{l}\text { Coolant outlet } \\
\text { and inlet nozzles } \\
\text { /safe ends }\end{array}$ & $\begin{array}{l}\text { SA508, Alloy } \\
600\end{array}$ & Fatigue, PWSCC & $\begin{array}{l}\text { Crack } \\
\text { initiation and } \\
\text { growth }\end{array}$ & $\begin{array}{l}\text { Primary } \\
\text { coolant leaks, } \\
\text { Loss of } \\
\text { primary } \\
\text { circuit } \\
\text { integrity }\end{array}$ & $\begin{array}{l}\text { Weld history; } \\
\text { Surface conditions, } \\
\text { Factors in Initiation } \\
\text { \& Propagation of } \\
\text { PWSCC }\end{array}$ & $\begin{array}{l}\text { Cracked specimens from } \\
\text { V.C. Summer \& Ringhals }\end{array}$ & $\begin{array}{l}\text { Specimens have } \\
\text { been obtained } \\
\text { from Summer and } \\
\text { Ringhals nozzles } \\
\text { to investigate the } \\
\text { failures. }\end{array}$ \\
\hline $\begin{array}{l}\text { Instrument } \\
\text { penetrations and } \\
\text { CRD housings }\end{array}$ & $\begin{array}{l}\text { SB166; SB167 } \\
\text { Alloy } 600\end{array}$ & $\begin{array}{l}\text { Fatigue; } \\
\text { PWSCC; Boric } \\
\text { acid corrosion }\end{array}$ & $\begin{array}{l}\text { Crack } \\
\text { initiation and } \\
\text { growth }\end{array}$ & CRD ejection & & $\begin{array}{l}\text { Repair destroys flaws, } \\
\text { consider material from an } \\
\text { RPV head that is being } \\
\text { replaced }\end{array}$ & \\
\hline RPV head & Carbon steel & $\begin{array}{l}\text { Boric acid } \\
\text { corrosion }\end{array}$ & $\begin{array}{l}\text { Loss of } \\
\text { material }\end{array}$ & RPV leakage & $\begin{array}{l}\text { Revised inspection } \\
\text { protocol }\end{array}$ & & \\
\hline
\end{tabular}


Table 3.2. PWR Steam Generator Tubes

\begin{tabular}{|c|c|c|c|c|c|c|c|}
\hline $\begin{array}{l}\text { Degradation } \\
\text { Sites }\end{array}$ & Materials & $\begin{array}{c}\text { Aging } \\
\text { Mechanisms }\end{array}$ & $\begin{array}{l}\text { Aging } \\
\text { Effects }\end{array}$ & Aging Issues & $\begin{array}{l}\text { Information } \\
\text { Needed }\end{array}$ & $\begin{array}{c}\text { Information/Samples } \\
\text { Availability }\end{array}$ & $\begin{array}{c}\text { Current } \\
\text { Resources and } \\
\text { Level of Efforts }\end{array}$ \\
\hline $\begin{array}{l}\text { Primary side of } \\
\text { steam generator } \\
\text { tubes } \\
\text { U-bends } \\
\text { Dented tubes } \\
\text { Exp. Trans. }\end{array}$ & $\begin{array}{l}600 \mathrm{MA} \\
600 \mathrm{TT} \\
690 \mathrm{SEN}\end{array}$ & $\begin{array}{l}\text { Primary water } \\
\text { stress corrosion } \\
\text { cracking; } \\
\text { Denting }\end{array}$ & $\begin{array}{l}\text { Crack } \\
\text { initiation and } \\
\text { growth }\end{array}$ & $\begin{array}{l}\text { Relation of } \\
\text { burst \& leak } \\
\text { performance } \\
\text { to NDE; } \\
\text { Safety } \\
\text { margins from } \\
\text { current } \\
\text { plugging } \\
\text { criteria; } \\
\text { Durability of } \\
\text { replacement } \\
\text { tubes }\end{array}$ & $\begin{array}{l}\text { Data on leak rate } \\
\text { and burst pressure } \\
\text { characteristics; } \\
\text { Correlation of crack } \\
\text { morphology with } \\
\text { tube failure } \\
\text { characteristics }\end{array}$ & $\begin{array}{l}\text { SG tube archive } \\
\text { inventory; Additional } \\
\text { tubes from operating or } \\
\text { shutdown plants }\end{array}$ & $\begin{array}{l}\text { ANL / NRC } \\
\text { studies on } \\
\text { laboratory- } \\
\text { induced cracks }\end{array}$ \\
\hline \multirow[t]{3}{*}{$\begin{array}{l}\text { Secondary side } \\
\text { of steam } \\
\text { generator tubes } \\
\text { TSP's Free } \\
\text { Spans TTS }\end{array}$} & $\begin{array}{l}\text { Carbon steel } \\
\text { ferritic SS, } \\
600 \mathrm{MA} \\
600 \mathrm{TT} \\
600 \mathrm{SEN} \\
690 \mathrm{TT}\end{array}$ & $\begin{array}{l}\text { Intergranular } \\
\text { corrosion/IGSCC }\end{array}$ & $\begin{array}{l}\text { Crack } \\
\text { initiation and } \\
\text { growth }\end{array}$ & & & & \\
\hline & & Pitting & $\begin{array}{l}\text { Leakage } \\
\text { through tube } \\
\text { walls }\end{array}$ & & & & \\
\hline & & Fretting & $\begin{array}{l}\text { Leakage } \\
\text { through tube } \\
\text { walls; } \\
\text { Reduction in } \\
\text { fatigue } \\
\text { strength }\end{array}$ & & & & \\
\hline
\end{tabular}


Table 3.2 (Contd)

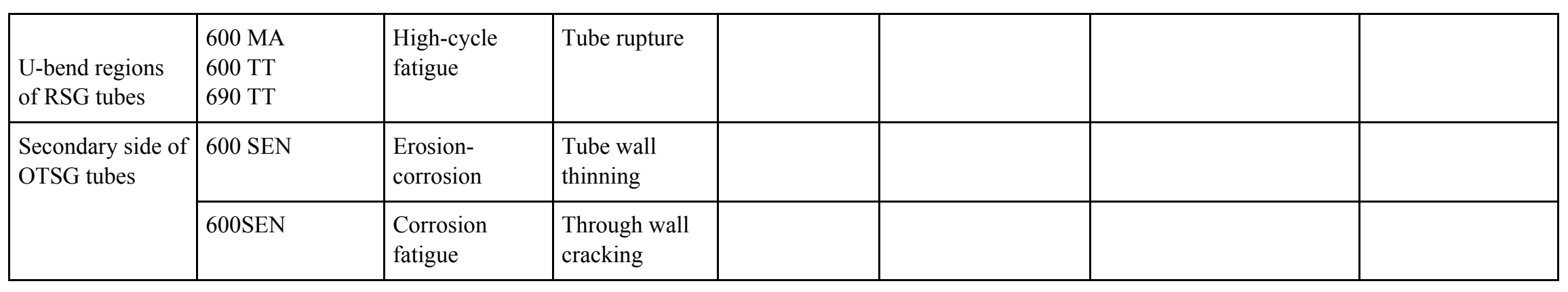




\section{Perspectives: Concrete Structures (Other Than Containments)}

Discussion with reactor staff resulted in a recommendation that attention be given to inspection of concrete structures, particularly in locations that are inaccessible in an operating reactor, possibly subject to aggressive conditions. This recommendation is consistent with a systematic study of concrete structures that led to conclusions that a) concrete structures have moderate seismic risk; b) are subject to degradation occurrences; and c) have a high need for further study (NUREG/CR-6679). Data from aged concrete structures are needed to benchmark models that are the basis for prediction of behavior of structures during seismic events.

A summary of plans for aging assessments at Big Rock Point as it is decommissioned, indicate that concrete samples will become available in 2004, when underground and underwater (intake pipe) structures are to be demolished. The decommissioning at SONGS-1 is ongoing in the time frame of 2000 through 2008. Coordination with the SONGS-1 decommissioning organization would indicate optimuim timing to inspect/sample concrete structures if needed.

The GALL report (NUREG-1801) indicates that further evaluation of BWR/PWR concrete foundations, domes, and walls is recommended if aging mechanisms are significant for inaccessible areas or if any portions of the concrete exceed specified temperature limits. The GALL report indicates further that all Class I structures Groups except Group 6, which are accessible, do not require further evaluation if within the scope of the applicant's structures monitoring program.

In NUREG/CR-6679, concrete containments were indicated to have low seismic risk and low need for further study. Table 3.3 summarizes aging issues needs for concrete structures (other than containments).

\section{Perspectives : BWR Vessel Internals}

While the structural materials used in BWR internals are essentially the same as are used in PWR internals, there are significant differences in the exposure conditions in the two reactor types. Foremost of these differences is the lower neutron flux, fluence and dpa levels to which the BWR internals are subjected. While PWR baffle-former assemblies can experience maximum neutron exposures approaching 100 dpa over a 40-year lifetime, the equivalent component, the BWR shroud, will experience maximum doses of only 3-7 dpa. The single exception is the top guide which will accumulate $\sim 20 \mathrm{dpa}$ on its bottom surface. At these lower exposure levels, void swelling and its concurrent effects on irradiation creep and void-embrittlement will be minimal, while in the PWR case, these, currently, are major issues.

The major issues in BWR internals are primarily concerned with cracking, both environmental and radiation-assisted. Cracking has been observed in many components, and radiation-assisted cracking has a relatively low dose threshold of 1-3 dpa. Due to differences in water chemistry between BWRs and PWRs, the nature of the cracking is often somewhat different and exhibits different thresholds for crack initiation. Thermal fatigue is the next most significant aging problem in BWRs. Table 3.4 summarizes aging issues and needs for investigation of BWR internals. 
Table 3.3. Other Seismic Category I Concrete Structures

\begin{tabular}{|c|c|c|c|c|c|c|c|}
\hline Components & Materials & $\begin{array}{c}\text { Aging } \\
\text { Mechanisms }\end{array}$ & $\begin{array}{l}\text { Aging } \\
\text { Effects }\end{array}$ & Aging Issues & $\begin{array}{c}\text { Information } \\
\text { Needed }\end{array}$ & $\begin{array}{c}\text { Information/Samples } \\
\text { Availability }\end{array}$ & $\begin{array}{c}\text { Current } \\
\text { Resources and } \\
\text { Level of Efforts }\end{array}$ \\
\hline $\begin{array}{l}\text { GROUP 1 } \\
\text { BWR reactor } \\
\text { building, } \\
\text { PWR shield } \\
\text { building, Control } \\
\text { room/building } \\
\text { GROUP } 2 \\
\text { BWR reactor } \\
\text { building with steel } \\
\text { superstructure } \\
\text { GROUP } 3 \\
\text { Auxiliary building, } \\
\text { Diesel generator } \\
\text { building, Radwaste } \\
\text { building, Turbine } \\
\text { building Switchgear } \\
\text { room, Auxiliary } \\
\text { feed water pump } \\
\text { house, Utility/piping } \\
\text { tunnel } \\
\text { GROUP } 4 \\
\text { Containment } \\
\text { internal structures } \\
\text { (excluding refueling } \\
\text { canal) } \\
\end{array}$ & $\begin{array}{l}\text { Concrete: } \\
\text { interior and } \\
\text { exterior } \\
\text { concrete, } \\
\text { concrete above } \\
\text { and below } \\
\text { grade; } \\
\text { masonry block } \\
\text { walls }\end{array}$ & $\begin{array}{l}\text { Internal } \\
\text { pressure due to } \\
\text { freeze-thaw } \\
\text { cycles } \\
\text { Leaching of } \\
\text { calcium } \\
\text { hydroxide } \\
\text { Aggressive } \\
\text { chemical attack } \\
\text { Reaction with } \\
\text { aggregates } \\
\text { Restraint; } \\
\text { Shrinkage; } \\
\text { Creep; } \\
\text { Aggressive } \\
\text { environment } \\
\text { Settlement } \\
\text { Corrosion of } \\
\text { embedded steel }\end{array}$ & $\begin{array}{l}\text { Scaling, } \\
\text { cracking, and } \\
\text { spalling; } \\
\text { Increase of } \\
\text { porosity and } \\
\text { permeability; } \\
\text { Cracking, and } \\
\text { spalling; } \\
\text { Loss of bond, } \\
\text { and loss of } \\
\text { embedding } \\
\text { steel material } \\
\text { Expansion and } \\
\text { cracking of } \\
\text { concrete; } \\
\text { Cracking of } \\
\text { masonry walls; } \\
\text { Basemat } \\
\text { cracking; } \\
\text { Distortion; } \\
\text { Increase in } \\
\text { component } \\
\text { stress level } \\
\\
\text { Leakage pool } \\
\text { water }\end{array}$ & $\begin{array}{l}\text { Effects of } \\
\text { age-related } \\
\text { degradation } \\
\text { on seismic } \\
\text { performance; } \\
\text { Reduction in } \\
\text { concrete } \\
\text { strength due } \\
\text { to age-related } \\
\text { degradation }\end{array}$ & $\begin{array}{l}\text { Bench marking } \\
\text { analytical } \\
\text { methodology to } \\
\text { predict response of } \\
\text { concrete elements, } \\
\text { including } \\
\text { relationships } \\
\text { between structure } \\
\text { characteristics } \\
\text { (strength, stiffness, } \\
\text { \& ductility) and } \\
\text { basic properties } \\
\text { (concrete } \\
\text { compressive } \\
\text { strength, bond } \\
\text { strength, concrete } \\
\text { areas and } \\
\text { reinforcing steel } \\
\text { areas); } \\
\text { Aging in } \\
\text { inaccessible areas } \\
\text { and on concrete } \\
\text { structures that } \\
\text { exceed specified } \\
\text { temperature limits } \\
\text { during operation }\end{array}$ & $\begin{array}{l}\text { Opportunities at plants } \\
\text { currently in } \\
\text { decommissioning i.e., Big } \\
\text { Rock Point and San Onofre } \\
1\end{array}$ & $\begin{array}{l}\text { Unknown; } \\
\text { Investigations at } \\
\text { reactors in } \\
\text { decommissioning } \\
\text { should be } \\
\text { considered }\end{array}$ \\
\hline
\end{tabular}


Table 3.4. BWR Vessel Internals

\begin{tabular}{|c|c|c|c|c|c|c|c|}
\hline Components & Materials & Aging Mechanisms & Aging Effects & Aging Issues & $\begin{array}{l}\text { Information } \\
\text { Needed } \\
\text { ( From Field } \\
\text { Components) }\end{array}$ & $\begin{array}{l}\text { Information/Samples } \\
\text { Availability } \\
\text { (BWRVIP Proprietary } \\
\text { Reports) }\end{array}$ & $\begin{array}{l}\text { Current } \\
\text { Resources and } \\
\text { Level of Efforts }\end{array}$ \\
\hline Core Shroud & 304,308 & $\begin{array}{l}\text { IGSCC, } \\
\text { IASCC, } \\
\text { Radiation hardening }\end{array}$ & $\begin{array}{l}\text { Environmental } \\
\text { Cracking, } \\
\text { Loss of } \\
\text { Fracture } \\
\text { Toughness }\end{array}$ & $\begin{array}{l}\text { Effect of } \\
\text { Fluence on } \\
\text { Crack Growth } \\
\text { and Fracture } \\
\text { Toughness }\end{array}$ & $\begin{array}{l}\text { Irradiated Core } \\
\text { Shroud Material for } \\
\text { IASCC and Fracture } \\
\text { Toughness Studies }\end{array}$ & $\begin{array}{l}\text { BWR Inspection and } \\
\text { Evaluation Guidelines } \\
\text { Issued: BWRVIP-76 } \\
\text { Crack Growth } \\
\text { Evaluation: BWRVIP- } \\
14\end{array}$ & \\
\hline $\begin{array}{l}\text { Core Shroud } \\
\text { Support }\end{array}$ & Alloy $182 / 600$ & IGSCC & $\begin{array}{l}\text { Environmental } \\
\text { Cracking }\end{array}$ & & $\begin{array}{l}\text { Metallurgical } \\
\text { Examination of } \\
\text { Cracked Core } \\
\text { Shroud Support } \\
\text { Material }\end{array}$ & $\begin{array}{l}\text { BWR Inspection and } \\
\text { Evaluation Guidelines } \\
\text { Issued: BWRVIP-38 } \\
\\
\text { Crack Growth } \\
\text { Evaluation: BWRVIP- } \\
59\end{array}$ & \\
\hline Top Guide & 304 & $\begin{array}{l}\text { IASCC, } \\
\text { Radiation hardening }\end{array}$ & $\begin{array}{l}\text { Environmental } \\
\text { Cracking, } \\
\text { Loss of } \\
\text { fracture } \\
\text { toughness }\end{array}$ & $\begin{array}{l}\text { Effect of } \\
\text { Fluence on } \\
\text { Crack Growth } \\
\text { and Fracture } \\
\text { Toughness }\end{array}$ & $\begin{array}{l}\text { Irradiated Core } \\
\text { Shroud Material for } \\
\text { IASCC and Fracture } \\
\text { Toughness Studies }\end{array}$ & $\begin{array}{l}\text { BWR Inspection and } \\
\text { Evaluation Guidelines I: } \\
\text { BWRVIP-26 }\end{array}$ & \\
\hline Core Plate & 304 & IGSCC & $\begin{array}{l}\text { Environmental } \\
\text { Cracking }\end{array}$ & & & $\begin{array}{l}\text { BWR Inspection and } \\
\text { Evaluation Guidelines: } \\
\text { BWRVIP-25 }\end{array}$ & \\
\hline
\end{tabular}


Table 3.4 (Contd)

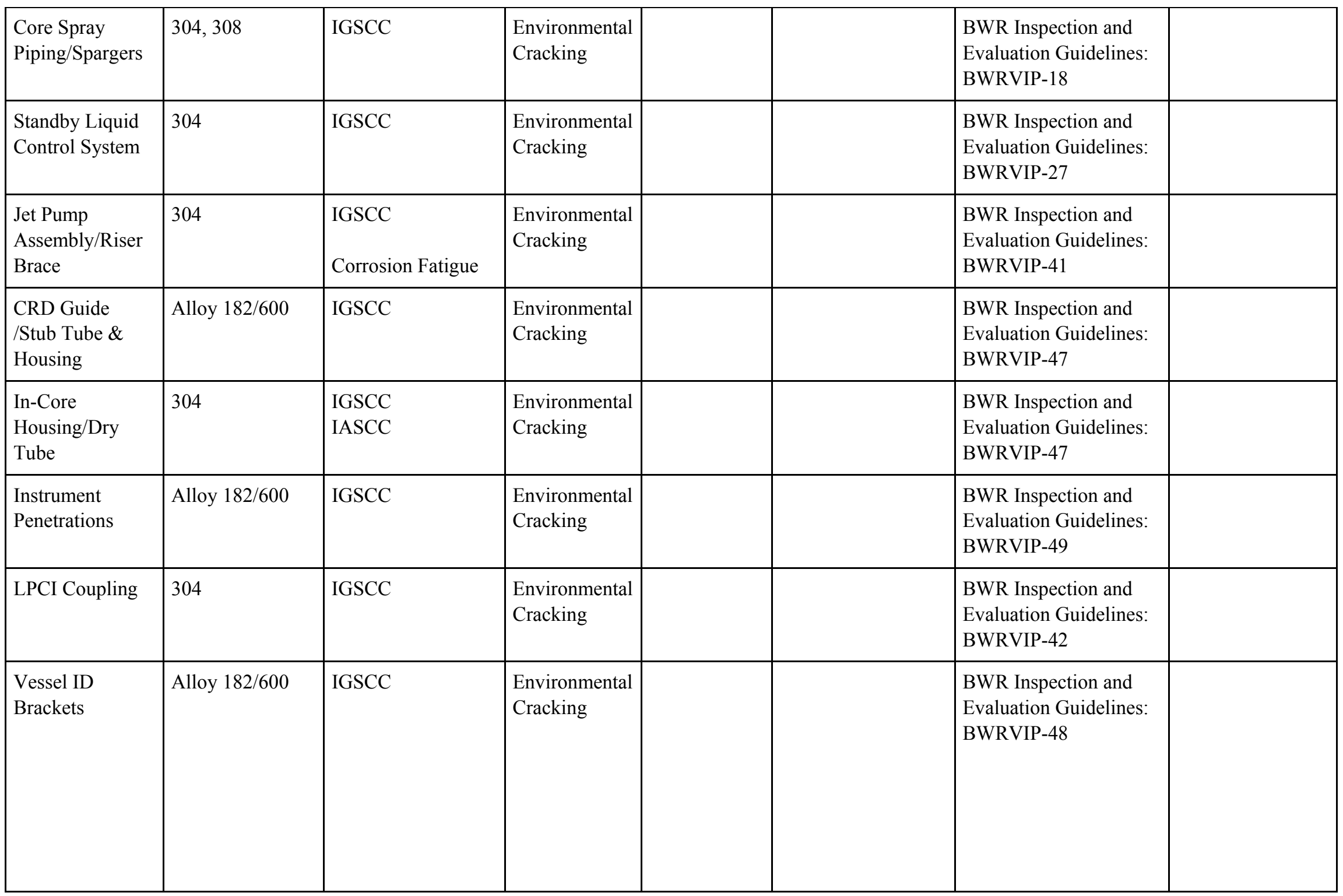


Table 3.4 (Contd)

\begin{tabular}{|c|c|c|c|c|c|}
\hline $\begin{array}{l}\text { Reactor Pressure } \\
\text { Vessel }\end{array}$ & $\begin{array}{l}\text { SS Clad SA533B } \\
\text { Cl } 1 \text { or A-302 B }\end{array}$ & $\begin{array}{l}\text { Neutron } \\
\text { Embrittlement } \\
\text { Corrosion Fatigue } \\
\text { SCC }\end{array}$ & $\begin{array}{l}\text { Loss of } \\
\text { Fracture } \\
\text { Toughness } \\
\\
\\
\text { Environmental } \\
\text { Cracking }\end{array}$ & & $\begin{array}{l}\text { BWR Inspection and } \\
\text { Evaluation Guidelines: } \\
\text { BWRVIP-74 } \\
\text { BWRVIP Integrated } \\
\text { Surveillance Program: } \\
\text { BWRVIP-78 } \\
\\
\text { Crack Growth } \\
\text { Evaluation: BWRVIP- } \\
60\end{array}$ \\
\hline $\begin{array}{l}\text { Access Hole } \\
\text { Cover }\end{array}$ & Alloy $182 / 600$ & IGSCC & $\begin{array}{l}\text { Environmental } \\
\text { Cracking }\end{array}$ & & GE SIL Issued \\
\hline Control Blades & 304 & IASCC & $\begin{array}{l}\text { Environmental } \\
\text { Cracking }\end{array}$ & $\begin{array}{l}\text { Irradiated Control } \\
\text { Blade Material for } \\
\text { IASCC and Fracture } \\
\text { Toughness Studies }\end{array}$ & \\
\hline
\end{tabular}




\section{PWR Vessel Internals}

Predominantly, PWR internals are constructed from austenitic stainless steels, although some are cast austenitic stainless steels (CASS). While austenitic steels are subject to some generic aging issues such as embrittlement, cracking, void swelling and irradiation creep, CASS has additional modes of embrittlement as a result of delta ferrite content.

Until recently, the primary aging concern associated with these steels used as internal components was cracking, either directly from environmental-assisted or radiation-assisted sources. A secondary concern was stress relaxation of preloaded components such as bolts and springs.

Current initiatives to implement license renewal have led to consideration of aging mechanisms that arise late in life, usually after an incubation period and frequently developing in a stronger than linear manner. Foremost of such aging concerns is void swelling, recently observed to develop in baffle bolts. Since swelling also accelerates irradiation creep and leads to a new mode of embrittlement, this aging mechanism requires study for its potential consequences on the continued functionality of internals.

Void swelling has been called out as an open license renewal technical issue. The GALL report (NUREG1801) states that a license renewal applicant must either provide the basis for concluding that void swelling is not an issue, or provide an aging management activity to manage both the effects of changes in dimension and any loss of ductility associated with void swelling. Table 3.5 summarizes aging issues and needs for naturally aged PWR vessel internals. 
Table 3.5. PWR Reactor Internals

\begin{tabular}{|c|c|c|c|c|c|c|c|c|c|}
\hline Components & Materials & $\begin{array}{c}\text { Aging } \\
\text { Mechanisms }\end{array}$ & Aging Effects & Aging Issues & $\begin{array}{c}\text { Data and } \\
\text { Information } \\
\text { Needs }\end{array}$ & $\begin{array}{c}\text { Evaluation } \\
\text { Needs }\end{array}$ & $\begin{array}{c}\text { Aging } \\
\text { Management } \\
\text { Needs/ } \\
\text { Options }\end{array}$ & $\begin{array}{l}\text { Information } \\
\text { /Samples } \\
\text { Availability }\end{array}$ & $\begin{array}{l}\text { Current Resources } \\
\text { being Applied and } \\
\text { Level of Efforts }\end{array}$ \\
\hline $\begin{array}{l}\text { Baffle-former- } \\
\text { barrel assembly, } \\
\text { including plates } \\
\text { and bolts }\end{array}$ & $\begin{array}{l}304,316,347 \\
\text { stainless steel, } \\
308 \text { welds }\end{array}$ & $\begin{array}{l}\text { Void swelling } \\
\text { Irradiation creep } \\
\text { Radiation } \\
\text { hardening } \\
\text { Radiation } \\
\text { induced } \\
\text { segregation }\end{array}$ & $\begin{array}{l}\text { Dimensional } \\
\text { distortion induced } \\
\text { by swelling and } \\
\text { irradiation creep } \\
\text { Creep relaxation } \\
\text { leading to } \\
\text { relaxation of } \\
\text { preloads on bolts } \\
\text { Loosened bolts } \\
\text { subject to fatigue } \\
\text { failure } \\
\text { Embrittlement by } \\
\text { 1) Environmental } \\
\text { cracking } \\
\text { (SCC,IASCC) } \\
\text { 2) Void-induced } \\
\text { embrittlement } \\
\text { 3) Creep-induced } \\
\text { embrittlement } \\
\text { Reduction of } \\
\text { fracture toughness }\end{array}$ & $\begin{array}{l}\text { Influence of } \\
\text { PWR-relevant } \\
\text { neutron spectra, } \\
\text { displacement } \\
\text { rates, and } \\
\text { variations of } \\
\text { thermal-to fast } \\
\text { neutron ratio on } \\
\text { swelling via gas } \\
\text { production and } \\
\text { transmutation } \\
\text { Impact of } \\
\text { temperature } \\
\text { variations } \\
\text { characteristic of } \\
\text { PWR operational } \\
\text { history } \\
\text { Effect of cold- } \\
\text { work on swelling } \\
\text { and irradiation } \\
\text { creep }\end{array}$ & $\begin{array}{l}\text { High fluence } \\
\text { swelling and } \\
\text { strain data from } \\
\text { both fast reactors } \\
\text { and PWRs. } \\
\text { Data on cracking } \\
\text { and unbolting } \\
\text { torques of baffle } \\
\text { bolts } \\
\text { Information on } \\
\text { fast reactor- } \\
\text { thermal reactor } \\
\text { correlation } \\
\text { methodology } \\
\text { High fluence } \\
\text { material changes } \\
\text { and influence on } \\
\text { structural } \\
\text { reliability } \\
\text { Flux effects on } \\
\text { swelling and } \\
\text { embrittlement }\end{array}$ & $\begin{array}{l}\text { Evaluate most } \\
\text { susceptible } \\
\text { locations for } \\
\text { swelling in } \\
\text { baffle-former- } \\
\text { barrel assemblies } \\
\text { Determine } \\
\text { synergistic } \\
\text { effects of } \\
\text { swelling and } \\
\text { creep relaxation } \\
\text { on structural } \\
\text { integrity of } \\
\text { bolted PWR } \\
\text { internals } \\
\text { assemblies } \\
\text { Determine } \\
\text { functional } \\
\text { capabilities of } \\
\text { bolted assemblies } \\
\text { including effects } \\
\text { of degradation } \\
\text { due to cracking, } \\
\text { swelling, creep } \\
\text { relaxation, and } \\
\text { reduction of } \\
\text { fracture } \\
\text { toughness }\end{array}$ & $\begin{array}{l}\text { Demonstrate the } \\
\text { use of current } \\
\text { inspection } \\
\text { techniques for } \\
\text { IASCC aging } \\
\text { management } \\
\text { (i.e., ability of } \\
\text { inspections to } \\
\text { detect mature } \\
\text { cracks in flaw } \\
\text { tolerant } \\
\text { components) }\end{array}$ & $\begin{array}{l}\text { Material changes } \\
\text { (hardening, } \\
\text { segregation, } \\
\text { swelling, creep } \\
\text { relaxation and } \\
\text { embrittlement) just } \\
\text { becoming available } \\
\text { on bolts at medium } \\
\text { exposure levels } \\
\\
\text { Data on } 304 \text { and } \\
316 \text { SS at high } \\
\text { fluence are } \\
\text { currently available } \\
\text { only from fast } \\
\text { reactors } \\
\text { Some limited LWR } \\
\text { creep data at } \\
\text { relatively low } \\
\text { fluence }\end{array}$ & $\begin{array}{l}\text { Most of these issues are } \\
\text { largely unexplored for PWR } \\
\text { application } \\
\text { MRP-ITG on PWR Internals } \\
\text { now preparing Technical } \\
\text { Basis Document on } \\
\text { swelling, creep and } \\
\text { embrittlement } \\
\text { MRP-ITG conducting an } \\
\text { assessment of aging } \\
\text { programs of PWR Internals } \\
\text { Some USDOE NERI and } \\
\text { NEPO programs directed } \\
\text { toward these issues } \\
\text { Some limited data on } \\
\text { cracking relationship to } \\
\text { microstructure and } \\
\text { irradiation conditions } \\
\text { becoming available from } \\
\text { CIR and JOBB programs }\end{array}$ \\
\hline
\end{tabular}


Table 3.5 (Contd)

\begin{tabular}{|c|c|c|c|c|c|c|c|c|c|}
\hline $\begin{array}{l}\text { Baffle-former } \\
\text { plates }\end{array}$ & $\begin{array}{l}\text { Annealed } \\
304 \text { stainless } \\
\text { steel, mostly } \\
\text { in the low } \\
\text { carbon } \\
\text { condition }\end{array}$ & $\begin{array}{l}\text { Void swelling } \\
\text { Creep and } \\
\text { swelling- } \\
\text { enhanced creep, } \\
\text { Void-induced } \\
\text { embrittlement } \\
\text { Cracking by } \\
\text { IASCC }\end{array}$ & $\begin{array}{l}\text { Loss of preload, } \\
\text { leading to loss of } \\
\text { mechanical } \\
\text { closure integrity, } \\
\text { allowing jetting, } \\
\text { cyclic loads, crack } \\
\text { initiation and } \\
\text { possible fatigue- } \\
\text { induced failure, } \\
\text { leading to missing } \\
\text { parts } \\
\text { Transverse loads } \\
\text { on bolts leading to } \\
\text { creep-induced } \\
\text { misalignment and } \\
\text { consequent } \\
\text { extraction } \\
\text { difficulty. } \\
\text { Changing stress } \\
\text { state with } \\
\text { swelling-creep } \\
\text { interaction of plate } \\
\text { and bolt }\end{array}$ & $\begin{array}{l}\text { High swelling in } \\
\text { re-entrant corners } \\
\text { in Westinghouse } \\
\text { and possibly CE } \\
\text { plants? } \\
\text { Calculation of } \\
\text { anisotropic } \\
\text { strains resulting } \\
\text { from constrained } \\
\text { swelling }\end{array}$ & $\begin{array}{l}\text { Swelling and } \\
\text { deformation } \\
\text { data from actual } \\
\text { plant } \\
\text { environment at } \\
\text { high neutron } \\
\text { exposure and } \\
\text { PWR-relevant } \\
\text { temperatures, } \\
\text { displace- } \\
\text { ment rates, dpa, } \\
\text { and neutron } \\
\text { spectra }\end{array}$ & $\begin{array}{l}\text { Determine } \\
\text { functional } \\
\text { capabilities of } \\
\text { baffle-former } \\
\text { plates structure } \\
\text { including } \\
\text { effects of } \\
\text { degradation due } \\
\text { to cracking, } \\
\text { swelling, creep } \\
\text { relaxation, and } \\
\text { reduction of } \\
\text { fracture } \\
\text { toughness } \\
\text { Perform } \\
\text { consequence } \\
\text { studies } \\
\text { including } \\
\text { effects of } \\
\text { swelling and } \\
\text { cracking }\end{array}$ & $\begin{array}{l}\text { Perform a } \\
\text { detailed } \\
\text { evaluation of the } \\
\text { existing and } \\
\text { planned research } \\
\text { programs to } \\
\text { determine their } \\
\text { applicability to } \\
\text { PWR internals } \\
\text { aging } \\
\text { management }\end{array}$ & $\begin{array}{l}\text { With exception of } \\
\text { earlier CHOOZ-A } \\
\text { data from EdF, no } \\
\text { PWR material from } \\
\text { plates is currently } \\
\text { available } \\
\text { Possibility to remove } \\
304 \text { baffle-former } \\
\text { bolts from CE plants } \\
\text { to assess swelling of } \\
\text { plate near bolt. Both } \\
\text { were constructed } \\
\text { from same steel }\end{array}$ & $\begin{array}{l}\text { NEPO-funded Task 3-30 } \\
\text { Directed toward in-situ NDT } \\
\text { measurement of strains } \\
\text { MRP-ITG is proceeding with } \\
\text { removal of some plate } \\
\text { segments and embedded bolts } \\
\text { from SONGS with possible } \\
\text { NEPO sponsorship to fund } \\
\text { examination }\end{array}$ \\
\hline
\end{tabular}


Table 3.5 (Contd)

\begin{tabular}{|c|c|c|c|c|c|c|c|c|c|}
\hline Baffle-former bolts & $\begin{array}{l}\text { Cold-worked } \\
316,347 \\
\text { stainless steel } \\
\text { in } \\
\text { Westinghouse } \\
\text { plants } \\
\text { Annealed } 304 \\
\text { in B\&W } \\
\text { plants }\end{array}$ & $\begin{array}{l}\text { Swelling } \\
\text { Irradiation } \\
\text { creep } \\
\text { Cracking due to } \\
\text { IASCC }\end{array}$ & $\begin{array}{l}\text { Loss of preload, } \\
\text { leading to loss of } \\
\text { mechanical } \\
\text { closure integrity, } \\
\text { allowing jetting, } \\
\text { cyclic loads, crack } \\
\text { initiation and } \\
\text { possible fatigue- } \\
\text { induced failure, } \\
\text { leading to missing } \\
\text { parts } \\
\text { Transverse loads } \\
\text { on bolts leading to } \\
\text { creep-induced } \\
\text { misalignment and } \\
\text { consequent } \\
\text { extraction } \\
\text { difficulty. } \\
\text { Changing stress } \\
\text { state with } \\
\text { swelling-creep } \\
\text { interaction of plate } \\
\text { and bolt }\end{array}$ & $\begin{array}{l}\text { Impact of plate } \\
\text { swelling and } \\
\text { differential } \\
\text { swelling of plate } \\
\text { and bolt on } \\
\text { cracking and bolt } \\
\text { integrity } \\
\text { Definition of } \\
\text { conditions } \\
\text { leading to bolt } \\
\text { cracking and } \\
\text { failure } \\
\text { Acceleration of } \\
\text { swelling in bolt } \\
\text { shank by stress? }\end{array}$ & $\begin{array}{l}\text { Swelling of } \\
\text { bolts as a } \\
\text { function of } \\
\text { temperature, } \\
\text { displacement } \\
\text { rate, dpa, stress } \\
\text { and service } \\
\text { conditions } \\
\text { Data on } \\
\text { cracking and } \\
\text { removal } \\
\text { problems }\end{array}$ & $\begin{array}{l}\text { Need model to } \\
\text { predict swelling } \\
\text { as a function of } \\
\text { temperature, } \\
\text { displacement } \\
\text { rate, dpa, stress } \\
\text { and service } \\
\text { conditions } \\
\text { Determine } \\
\text { reduction in } \\
\text { pre-load } \\
\text { necessary to } \\
\text { cause loss of } \\
\text { function for a } \\
\text { single bolt, pin, } \\
\text { or fastener } \\
\text { Identify key } \\
\text { bolts (or } \\
\text { number of } \\
\text { bolts) from } \\
\text { cracking and } \\
\text { functionality } \\
\text { standpoint } \\
\text { Need a } \\
\text { sufficient } \\
\text { database, along } \\
\text { with an } \\
\text { empirical } \\
\text { model, to } \\
\text { predict the } \\
\text { amount of } \\
\text { degradation due } \\
\text { to IASCC in } \\
\text { baffle-former } \\
\text { bolts }\end{array}$ & $\begin{array}{l}\text { Perform options } \\
\text { studies to } \\
\text { determine cost- } \\
\text { effective } \\
\text { inspections, } \\
\text { monitoring, or } \\
\text { corrective actions }\end{array}$ & $\begin{array}{l}\text { Surveillance data } \\
\text { from various EdF } \\
\text { plants } \\
\text { Recent examination } \\
\text { data being developed } \\
\text { on bolts from US } \\
\text { reactors } \\
\text { Additional data is } \\
\text { needed on bolt } \\
\text { survival or failure } \\
\text { across a wider range } \\
\text { of irradiation } \\
\text { conditions }\end{array}$ & $\begin{array}{l}\text { Some data on } 316 \text { bolts from } \\
\text { Tihange (CIR program) } \\
\text { Some } 316,347 \text { bolt data from } \\
\text { Farley, Ginna and Point Beach } \\
\text { are now being generated by } \\
\text { MRP-ITG program on internals } \\
\text { Some potential bolt data is } \\
\text { possible from material to be } \\
\text { removed from SONGS }\end{array}$ \\
\hline
\end{tabular}


Table 3.5 (Contd)

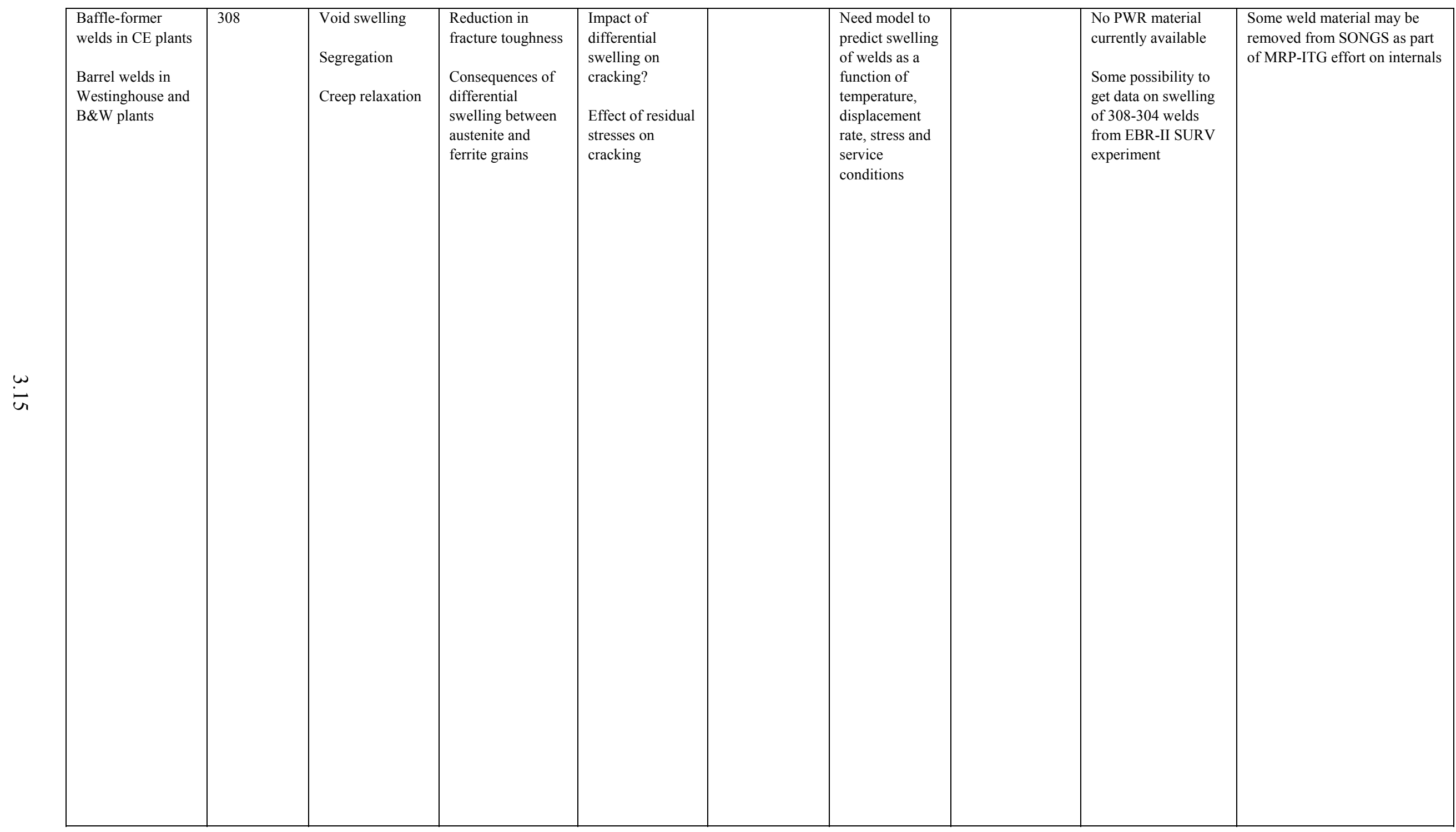


Table 3.5 (Contd)

\begin{tabular}{|c|c|c|c|c|c|c|c|c|}
\hline $\begin{array}{l}\text { Core shroud } \mathrm{B} \& \mathrm{~W} \\
\text { reactor }\end{array}$ & $\begin{array}{l}\text { Cast } \\
\text { austenitic } \\
\text { stainless } \\
\text { steels CASS }\end{array}$ & $\begin{array}{l}\text { Thermal } \\
\text { embrittlement } \\
\text { Irradiation } \\
\text { embrittlement } \\
\text { Irradiation creep } \\
\text { and swelling } \\
\text { Cracking }\end{array}$ & $\begin{array}{l}\text { Reduction in } \\
\text { fracture toughness } \\
\text { Consequences of } \\
\text { differential } \\
\text { swelling between } \\
\text { austenite and } \\
\text { ferrite grains }\end{array}$ & $\begin{array}{l}\text { Behavior of } \\
\text { static cast vs. } \\
\text { centrifugal cast } \\
\text { material } \\
\text { Effect of ferrite } \\
\text { level on } \\
\text { embrittlement }\end{array}$ & $\begin{array}{l}\text { Fracture } \\
\text { toughness data } \\
\text { on both } \\
\text { thermally aged } \\
\text { and irradiated } \\
\text { CASS to } \\
\text { evaluate } \\
\text { synergistic } \\
\text { effects for } \\
\text { fluence levels } \\
\sim 10^{20} \mathrm{n} / \mathrm{cm}^{2} \\
(\mathrm{E}>1 \mathrm{MeV}) \\
\text { Need additional } \\
\text { irradiation } \\
\text { embrittlement } \\
\text { and fracture } \\
\text { toughness data } \\
\text { for fluence } \\
\text { levels }>8 x 10^{20} \\
\mathrm{n} / \mathrm{cm}^{2}(\mathrm{E}>1 \\
\text { MeV), in order } \\
\text { to determine } \\
\text { possible } \\
\text { saturation } \\
\text { effects and to } \\
\text { extend generic } \\
\text { flaw tolerance } \\
\text { analyses }\end{array}$ & $\begin{array}{l}\text { Demonstrate that } \\
\text { fluence threshold } \\
\text { should be raised } \\
\text { to at least } 1 \times 10^{20} \\
\text { n/cm }(\mathrm{E}>1 \\
\mathrm{MeV} \text { ) for CASS } \\
\text { components in } \\
\text { PWR coolant } \\
\text { environment } \\
\text { Verify that for } \\
\text { components } \\
\text { below this } \\
\text { threshold, the } \\
\text { screening criteria } \\
\text { on Mo content, } \\
\text { delta ferrite } \\
\text { content, and } \\
\text { casting type } \\
\text { should be applied } \\
\text { For CASS } \\
\text { components } \\
\text { subjected to } \\
\text { neutron fluence > } \\
1 \times 10^{20} \mathrm{n} / \mathrm{cm}{ }^{2} \text { (E } \\
>1 \mathrm{MeV} \text { ), } \\
\text { demonstrate that } \\
\text { the component is } \\
\text { flaw tolerant } \\
\text { under Service } \\
\text { Level A, B, C, } \\
\text { and D loads } \\
\text { Argue that } \\
\text { Examination } \\
\text { Category B-N-3 } \\
\text { visual (VT-3) } \\
\text { inspections are } \\
\text { adequate for } \\
\text { mature cracks in } \\
\text { flaw tolerant } \\
\text { components } \\
\text { (instead of EVT- } \\
\text { 1) }\end{array}$ & $\begin{array}{l}\text { No material currently } \\
\text { identified }\end{array}$ & $\begin{array}{l}\text { Maine Yankee and SONGS } \\
\text { efforts to procure irradiated } \\
\text { CASS have been unsuccessful }\end{array}$ \\
\hline
\end{tabular}


Table 3.5 (Contd)

\begin{tabular}{|c|c|c|c|c|c|c|c|}
\hline $\begin{array}{l}\text { Other support } \\
\text { internals at low } \\
\text { exposure, below } \\
10^{20} \mathrm{n} / \mathrm{cm}^{2} \mathrm{E}>1.0 \\
\mathrm{MeV}\end{array}$ & $\begin{array}{l}\text { Cast } \\
\text { austenitic } \\
\text { stainless } \\
\text { steels CASS }\end{array}$ & $\begin{array}{l}\text { Thermal } \\
\text { embrittlement } \\
\text { Irradiation } \\
\text { embrittlement } \\
\text { Cracking }\end{array}$ & $\begin{array}{l}\text { Behavior of } \\
\text { static cast vs. } \\
\text { centrifugal cast } \\
\text { material } \\
\text { Effect of ferrite } \\
\text { level on } \\
\text { embrittlement }\end{array}$ & $\begin{array}{l}\text { Fracture } \\
\text { toughness data } \\
\text { on both } \\
\text { thermally aged } \\
\text { and irradiated } \\
\text { CASS in order } \\
\text { to raise } \\
\text { surveillance } \\
\text { threshold from } \\
\text { NRC-mandated } \\
10^{17} \text { to } 10^{20} \\
\mathrm{n} / \mathrm{cm}^{2}\end{array}$ & $\begin{array}{l}\text { Determine the } \\
\text { extent of } \\
\text { potential } \\
\text { damage for } \\
\text { PWR internals } \\
\text { from the effects } \\
\text { of irradiation } \\
\text { embrittlement } \\
\text { and thermal } \\
\text { aging of CASS }\end{array}$ & $\begin{array}{l}\text { No material currently } \\
\text { identified }\end{array}$ & None \\
\hline
\end{tabular}




\section{Thermally-Aged Cast Stainless Steels (CASSs)}

The CASSs are subject to embrittlement by both thermal and radiation mechanisms. Radiation effects are addressed under BWR and PWR Reactor Internals matrices. Thermally-aged CASSs exist in pump bowls, valve bodies and RCS piping. Examination of CASSs by ultrasonic methods is difficult because the large grain structure tends to disperse the signals. Even so, plant operators are required to perform NDE, even though it is generally marginally effective. This dilemma is currently being assessed by an ASME committee. On one hand, there is the perspective that there are very few cases of failure in CASS pipes. On the other hand, there is a recommendation that selected hot-leg pipe runs (selected based on highest temperature locations and longest years of operation) be removed from shutdown plants, focusing on weld locations, as the probable worst-case site for degradation if it is developing. Twenty-six U.S. PWRs have CASS RCS piping. At the Farley PWR, a through-wall thermal fatigue crack developed in a CASS surge line, although until now CASS components have had low incidence of failure. The GALL report (NUREG-1801) indicates that further evaluation of CASS PWR RCS piping is recommended on a plant specific basis. In the GALL report, it is suggested that further evaluation is not needed for BWR/PWR pump casings and valve bodies. The need suggested here is to evaluate whether there is a satisfactory basis to mitigate or modify application of NDE on CASS piping (involving unnecessary personal exposure). Table 3.6 summarizes aging issues and needs for naturally aged cast SSs. 
Table 3.6. Cast Stainless Steel (Thermally Aged)

\begin{tabular}{|c|c|c|c|c|c|c|c|}
\hline Components & Materials & $\begin{array}{c}\text { Aging } \\
\text { Mechanisms }\end{array}$ & $\begin{array}{l}\text { Aging } \\
\text { Effects }\end{array}$ & Aging Issues & $\begin{array}{l}\text { Information } \\
\text { Needed }\end{array}$ & $\begin{array}{c}\text { Information } \\
\text { /Samples } \\
\text { Availability }\end{array}$ & $\begin{array}{c}\text { Current } \\
\text { Resources being } \\
\text { Applied and } \\
\text { Level of Efforts }\end{array}$ \\
\hline $\begin{array}{l}\text { PWR RCS } \\
\text { Piping }\end{array}$ & CF8M & $\begin{array}{l}\text { Thermal } \\
\text { embrittlement; } \\
\text { Fatigue } \\
\text { cracking, } \\
\text { Radiation } \\
\text { embrittlement }\end{array}$ & $\begin{array}{l}\text { Crack } \\
\text { initiation } \\
\text { \& growth }\end{array}$ & $\begin{array}{l}\text { Compro- } \\
\text { mises } \\
\text { pressure } \\
\text { boundary; } \\
\text { NDE is } \\
\text { required but } \\
\text { does not } \\
\text { effectively } \\
\text { detect pipe } \\
\text { defects }\end{array}$ & $\begin{array}{l}\text { Evidence of } \\
\text { whether cracks } \\
\text { are forming \& } \\
\text { propagating in } \\
\text { RCS pipes }\end{array}$ & $\begin{array}{l}\text { Need access to } \\
\text { locations most } \\
\text { likely to degrade, } \\
\text { i.e., at welds }\end{array}$ & $\begin{array}{l}\text { EPRI MRP } \\
\text { project to } \\
\text { compile thermal } \\
\text { aging data }\end{array}$ \\
\hline
\end{tabular}




\section{Perspective: Buried Piping and Tanks}

A study of age-related degradation of structures and passive components included assessment of buried piping (NUREG/CR-6679). Based on plant data (LERs, ${ }^{1}$ NPRDS $^{2}$ ) and walk downs of six U.S. NPPs, the seismic risk of buried piping was rated as High, degradation occurrences were rated Unknown (due to a paucity of inspection results), and need for further study was rated as "High". Concern was indicated that degraded buried piping could pose difficulties in adequate cooling water flow, particularly in the event that there is differential settling of the pipe during a seismic event.

Input from plant staff included a recommendation to assess the condition of buried piping. Coatings on the pipe OD do not have an identified qualified life. Some plants assess degradation of buried piping by inspection of the condition of the pipe ID surface. Degradation from OD surfaces is only detected when evidence appears on ID surfaces. Some plants have piping that is not sufficiently large to accommodate internal inspection.

Buried tanks are included here because they have similar vulnerabilities and lack of systematic inspection that apply to buried piping.

The GALL report (NUREG-1801) indicates that BWR/PWR buried piping and fittings need further evaluation, related to inspection to detect aging effects and to evaluate operating experience. Further evaluation is also recommended in the GALL report for buried tanks (e.g., condensate storage tanks). Table 3.7 summarizes aging issues and needs for assessment of naturally aged buried piping and tanks.

\section{Flat Bottom Tanks}

Flat bottom tanks are generally cylindrical, with bottoms resting on concrete pads. They may be located inside a building or exposed to the elements. The crevice between the tank and the concrete pad may be difficult to inspect. Flat bottom tanks were identified in NUREG/CR-6679 as having very high seismic risk significance, high incidence of degradation, and high priority ranking for further study. To cite an example, a condensate storage tank was observed to have degradation of the water seal at the base of the tank and corrosion of the tank bottom plate (NUREG-1522). An element of seismic risk involves sloshing of liquid during a seismic event, but age-related degradation could constitute a potential factor in reducing tank integrity. To the extent that the tanks have areas where measurement of wall thickness and tank mechanical integrity are difficult to assess, investigations on selected areas of the tanks as they are removed in decommissioning is recommended.

The GALL report (NUREG-1801) indicates that detection of aging effects in diesel oil fuel tanks is to be further evaluated. Table 3.8 summarizes aging issues and needs for assessment of naturally aged flat bottom tanks.

\footnotetext{
${ }^{1}$ LER: licensee event report

${ }^{2}$ NPRDS: nuclear plant reliability data system
} 
Table 3.7. Buried Piping and Tanks

\begin{tabular}{|l|l|l|l|l|l|l|l|}
\hline \multicolumn{1}{|c|}{ Components } & \multicolumn{1}{|c|}{ Materials } & \multicolumn{1}{|c|}{$\begin{array}{c}\text { Aging } \\
\text { Mechanisms }\end{array}$} & Aging Effects & Aging Issues & $\begin{array}{c}\text { Information } \\
\text { Needed }\end{array}$ & $\begin{array}{c}\text { Information/Sa } \\
\text { mples } \\
\text { Availability }\end{array}$ & $\begin{array}{c}\text { Current } \\
\text { Resources and } \\
\text { Level of Efforts }\end{array}$ \\
\hline $\begin{array}{l}\text { System piping } \\
\text { (e.g. service } \\
\text { water, fire } \\
\text { protection diesel } \\
\text { fuel); tanks (e.g. } \\
\text { diesel fuel at } \\
\text { some plants) }\end{array}$ & $\begin{array}{l}\text { Carbon steel; ID } \\
\text { and OD coatings; } \\
\text { wrappings }\end{array}$ & $\begin{array}{l}\text { Loss of material; } \\
\text { MIC. Coating } \\
\text { and wrapping } \\
\text { degradation }\end{array}$ & $\begin{array}{l}\text { Leakage; loss of } \\
\text { integrity in } \\
\text { seismic events }\end{array}$ & $\begin{array}{l}\text { Assuring pipe \& } \\
\text { tank integrity in } \\
\text { normal operation } \\
\text { and in seismic } \\
\text { events }\end{array}$ & $\begin{array}{l}\text { Type, severity of } \\
\text { piping and tank } \\
\text { degradation }\end{array}$ & $\begin{array}{l}\text { Examination of } \\
\text { piping \& tanks as } \\
\text { they are removed } \\
\text { during } \\
\text { decommissioning }\end{array}$ & $\begin{array}{l}\text { Not currently } \\
\text { addressed. } \\
\text { Consider } \\
\text { opportunities at } \\
\text { BRP \& SONGS. }\end{array}$ \\
\hline
\end{tabular}


Table 3.8. Flat Bottom Tanks

\begin{tabular}{|c|c|c|c|c|c|c|c|}
\hline $\begin{array}{l}\text { Components } \\
\text { Outdoors }\end{array}$ & Materials & $\begin{array}{c}\text { Aging } \\
\text { Mechanisms }\end{array}$ & Aging Effects & Aging Issues & $\begin{array}{c}\text { Information } \\
\text { Needed }\end{array}$ & $\begin{array}{c}\text { Information } \\
\text { /Samples } \\
\text { Availability }\end{array}$ & $\begin{array}{c}\text { Current } \\
\text { Resources Being } \\
\text { Applied and } \\
\text { Level of Efforts }\end{array}$ \\
\hline $\begin{array}{l}\text { Examples: } \\
\text { Condensate } \\
\text { storage tanks; } \\
\text { Reactor water } \\
\text { storage tanks; } \\
\text { Diesel fuel storage } \\
\text { tanks }\end{array}$ & $\begin{array}{l}\text { Carbon } \\
\text { Steel } \\
\text { Coatings (Interior } \\
\text { and Exterior) }\end{array}$ & $\begin{array}{l}\text { Loss of material } \\
\text { (pitting \& crevice } \\
\text { corrosion) }\end{array}$ & $\begin{array}{l}\text { Decreased wall } \\
\text { thickness; } \\
\text { Increased fragility; } \\
\text { Leakage if wall is } \\
\text { penetrated }\end{array}$ & $\begin{array}{l}\text { Increased seismic } \\
\text { risk significance; } \\
\text { Possible leakage }\end{array}$ & $\begin{array}{l}\text { Wall thickness } \\
\text { and mechanical } \\
\text { property } \\
\text { measurements, } \\
\text { particularly on } \\
\text { tank bottoms in } \\
\text { crevice areas }\end{array}$ & $\begin{array}{l}\text { Wall thickness } \\
\text { measurements \& } \\
\text { specimen removal } \\
\text { from tanks } \\
\text { removed during } \\
\text { decommissioning }\end{array}$ & \\
\hline
\end{tabular}




\subsection{Secondary Candidates}

Certain CMSs were indicated as having caused problems by plant staffs or were otherwise judged to have merit for consideration as candidates for resolution of aging issues. Those addressed here were not included in the list of primary CMSs, but in future considerations, some may emerge as having merit for assessment of naturally aged candidates.

\section{Masonry Walls:}

Identified in NUREG/CR-6679 as having very high seismic risk, high degradation occurrences, and very high need for further study. Collapse of a wall in a seismic event could damage safety-related equipment. In general, the walls seem accessible to inspection, which is the basis for not including them on the list of leading CMSs. However, to the extent that wall locations exist that are difficult to inspect during reactor service, there may be motivation to systematically assess wall conditions during decommissioning.

\section{Concrete Containments:}

Identified in NUREG/CR-6679 as having low seismic significance, high degradation occurrences (concrete leaching, spalling, etc.), but low ranking for further study. Some concern was expressed by plant staff regarding corrosion of the metal liner plate. Generally, these phenomena are subject to aging assessment and management by existing aging management programs; therefore, concrete containments are not promoted to the priority list. However, the GALL report indicates that further evaluation of BWR/PWR containment steel elements (liner plate and containment shell) is recommended if corrosion may be significant in inaccessible areas. In cases where water is trapped between the concrete wall and the liner plate, the water can percolate to the floor plate and cause pitting corrosion.

\section{Metal Containments}

The consequence of a full penetration of a metal containment wall is loss of containment. Shutdown reactors with metal containments could be assessed at key locations. Reactors with metal containments remain in operation and may be candidates for license renewal. Inspection of vulnerable areas of metal containments should be factored into decommissioning operations. A study of age-related degradation of structures and passive components (NUREG/CR-6679) indicates that steel containments have insufficient data to determine seismic risk. Degradation occurrences are rated "High". Priority ranking for further study is rated "Low", presumably because relatively few plants in operation have metal containments. They are included here because plants with metal containments that may apply for license renewal could benefit from information from shutdown plants. The SONGS-1 plant, now in decommissioning, has a metal containment.

\section{Anchorages}

Anchorage to concrete is required for heavy machinery, structural members, piping, ductwork, cable trays, towers, and other structure types. The anchorages involve metal heads that are embedded in concrete to secure prestressing tendons; also, resin or chemical anchors. NUREG/CR-6679 indicates 
that anchorages have high seismic risk, high degradation occurrences, and high need for further study. Anchorages are included here to prompt consideration of possible opportunities to include assessments during decommissioning now underway at Big Rock Point and SONGS-1.

Note: The GALL report (NUREG-1801) indicates that prestressed containment tendons are subject to TLAA for loss of prestress due to relaxation, shrinkage, creep, and elevated temperature.

\section{Instrumentation and Power Cable}

An industry-based program to assess cable aging is being conducted by EPRI and Sandia National Laboratory.(SNL). It involves investigation of cable materials artificially aged under systematically controlled thermal and radiation conditions that are relevant to conditions encountered in service. The program also involves a study under reactor conditions in closely monitored environments. The principal aging mechanisms are thermal and radiation embrittlement of cable insulation. Seventy percent of the insulation materials are cross-linked polyethylene and ethylene propylene rubber. The industry-based program does not currently include plans for accessing naturally aged cable from shutdown plants beyond the study that is ongoing, due to difficulty in locating cable with reliable histories, observations that properties differ from length to length in a given cable, and difference in cable types and environments from plant to plant.

The NRC has sponsored cable studies at BNL that have included naturally aged medium voltage power cables. Results of these studies are provided in NUREG/CR-6704. Currently, the NRC program does not involve naturally aged materials. Rather, the current focus is on collection and interpretation of operating experiences from LERs and NPRDS.

Even though neither regulatory nor industry programs seem to have immediate plans for expanded access to naturally aged cables, cables are included, prompted by possible future interest in naturally aged cable materials. There are also aging issues with cable splices.

\section{Supports for Equipment and Systems}

Supports are identified in NUREG/CR-6679 as having high seismic risk significance, moderate degradation occurrences, and moderate ranking for further study. However, the need for further study is mitigated because supports are generally accessible and subject to existing aging management programs.

\section{Non-ASME Structural Steel Bolted Joints}

Investigation of bolted joints was recommended in one interview. The GALL report indicates that closure bolting of carbon steel and low alloy steel components does not require further evaluation. Further evaluation is also not required for closure bolting in high-pressure or high-temperature systems.

\section{Small Bore Piping}

Piping not subject to ASME requirements was recommended to be considered for investigation. The GALL Report (NUREG-1801, Vol. 1) indicates that aging degradation occurs by SCC, IGSCC, and 
thermal and mechanical loading. The report recommends further evaluation. The key issue is whether small bore piping aging issues can be effectively addressed by existing aging management programs or whether access to degraded naturally aged pipe will advance understanding of the aging degradation and how aging management can be improved. There have been numerous small-bore piping failures but with limited impact on plant safety. Small bore piping issues are addressed separately in the following sections:

\section{Thermal Fatigue}

A relatively small number of thermal fatigue related failures have occurred in small-bore piping. Of those that have occurred, the more common source of thermal fatigue was either (1) cracking associated with the interaction of valve leakage and cyclic effects (i.e., check valve upstream pressure cycling, turbulent penetrations, etc.) and (2) cyclic turbulent penetration effects of isolated small-bore piping or drain lines. These concerns are managed as part of the plant's in-service inspection program and/or augmented inspection programs mandated by the NRC.

\section{Stress Corrosion Cracking}

For BWRs, this mechanism in small-bore piping is identified and managed as part of the plant's Generic Letter (GL) 88-01 IGSCC program. For PWRs, SCC issues relevant to small-bore piping are associated with PWSCC of nickel-based alloys and SCC in stagnant austenitic stainless steel piping with oxygenated water and/or initiating contaminants. For PWRs these mechanisms are managed as part of plant in-service inspection programs.

\section{Mechanical Fatigue}

Small bore pipe (< inch, NPS) and socket welded vent and drain connections in the immediate proximity of vibration sources tend to be most susceptible to high cycle mechanical fatigue in operating nuclear power plants. Unlike the previously discussed mechanisms, vibration fatigue does not lend itself to periodic in-service examinations (i.e., volumetric, surface, etc.) as a means of managing this degradation mechanism. The nature of this mechanism is such that, generally, almost the entire fatigue life of the component is expended during the initiation phase. Once a crack initiates, failure quickly follows. Consequently, the absence of any detectable crack may not necessarily assure reliable component performance. In addition, for many of these components, the plant conditions when vibration levels are unacceptable may be difficult to predict and limited to short time periods of unique plant/system configurations. This would explain why cases continue to be observed where vibration fatigue failures occur late in the plant's operating life. Therefore, the fact that a vibration failure has not occurred within the first few years of plant operation may not preclude future failures. Historically this problem has been handled on a case-by-case basis. Generally, once susceptible locations have been identified, correcting design and/or fabrication problems associated with the as-built condition eliminates the mechanical fatigue problem.

\section{Radiation-Induced Degradation of Coatings on Concrete Inside Containment}

This issue was raised in a discussion with plant staff. The consequence was indicated to be plugging of sump screens by delaminated paint strips. The coatings degrade in containment due to thermal and 
radiation effects. The U.S. NRC has assessed the phenomenon, based on analytical and experimental initiatives, to develop sufficient understanding to determine further actions needed, from engineering and risk perspectives (NRC 2001a). Industry groups have also joined the effort to understand and mitigate the problem. Research addressing containment protective coatings is scheduled for completion in FY 2002. Research related to the PWR sump blockage problem is slated for completion in FY 2003. It is presumed that if assessment of coating condition in shutdown plants will be useful to the research, that it will be factored into the research programs. 


\subsection{Component Analysis and Selection}

Once there is broad agreement on the list of primary CMS candidates, the next action is to identify specific targets for assessment. The process needs to involve systematic considerations that will assure that when a specific candidate is recommended for funding, that the investment in the candidate will result in effective resolution of a leading aging issue, guided by the criteria in Section 4.1. Identifying the most cost-effective option involves considerations indicated in Section 4.2.

\subsection{Criteria for Selection of Candidate Materials/Components}

The criteria outlined as follows will guide the selection of candidates to be acquired and examined:

The candidate addresses an aging issue that has a clearly defined need that is not effectively addressed by ongoing programs.

The candidate addresses an issue that has sufficiently broad application to justify the investment.

The owner or custodian of the candidate is in full agreement regarding candidate availability, including time frame. Conditions for release of information regarding the candidate must be spelled out.

Historical, environmental, and compositional information regarding the candidate are confirmed to be available in requisite detail.

The candidate can be acquired and examined in a timeframe that provides timely resolution of the relevant issue.

The total cost to acquire, examine, and dispose of the candidate is justified by the importance of the issue that will be resolved. Cost analysis for radioactive components or that will be accessed in radioactive areas must include all impacts, including safety, imposed by the radioactivity considerations of the candidate and/or the working environment, including accessing, removal, packaging, shipping, analysis, and disposal, for all actions that apply.

Candidates in shutdown plants or that have been removed from service in operating plants have not been compromised by post-service degradation.

The intended role of this or a similar systematic program would be to provide a sufficient analysis that a potential funding organization would have a satisfactory basis to make a funding decision or to issue a request for proposal.

\subsection{Options for Investigation of Naturally Aged Materials/Components}

An essential aspect of the analysis is to identify the level of action that will be needed to facilitate effective resolution of the aging issue being addressed. Approaches to utilize naturally aged components to investigate the status of age-related degradation include those indicated here: 
- In situ non-destructive measurements, for example, to investigate wall thinning or to detect cracks

- In situ invasive measurements, for example, removal of a material specimen from a component surface, wall, etc., or removal of a subcomponent for examination or testing

- Removal of an entire component assembly for testing or dismantlement to observe effects of aging.

Levels of investigation of naturally aged materials/components have involved a range of complexities, from visual observations to in situ measurements, to extended measurements in various laboratories, illustrated by the Shippingport Decommissioning Program ( Allen and Johnson 1990), or to multi-year, multi-sponsor investigations of a major component, illustrated by the Surry SG program (Kurtz et al. 1990). The Shippingport and Surry SG initiatives are summarized in later sections. The Surry SG program offers a model for addressing a high-cost initiative, such as obtaining specimens from a reactor pressure vessel that may depend on technical and financial cooperation of multiple organizations.

\subsection{Aging Management in License Renewal}

It is important for this project to include recognition of the scope of aging assessment and management as they apply in the period of LR.

In the U.S., nuclear plant licenses are issued for a period of 40 years. Renewal of the license permits operation for an additional 20 years. The first operating licenses of U.S. NPPs expire in 2006.

Approximately 10 percent of the 102 remaining licenses expire by the end of the year 2010, and more than 40 percent expire by the year 2015. The decision to apply for LR is entirely the decision of the plant owners. Their decision is based on the economic prospects of the plant and whether it can meet NRC requirements (TIP-01 2000).

In 1995, the NRC finalized requirements for renewal of NPP operating licenses and issued the LR rule, 10CFR Part 54. These requirements are in addition to existing safety requirements defined by 10CFR Part 50. The rule is intended to provide additional assurance that effects of aging will be properly managed through the reactor service life. A draft Standard Review Plan for the Review of License Renewal (SRP-LR), dated August 2000, has been revised to incorporate information from the "Generic Lessons Learned" (GALL) report and to incorporate lessons learned from the staff review of the initial license renewal applications (LRAs).

The focus for LR review is on passive, long-lived structures and components, including components addressed by TLAA. The TLAAs focus on components that have been qualified for operation during the 40-year license, for example, on the basis that performance will be satisfactory for a given number of cycles or for a projected neutron dose or some other characteristic. For extended operation, confirmation is required that additional cycles or other operational factors occurring during LR do not compromise safe operation of the components. Examples of TLAAs are tendon pre-stress for concrete containments; reactor building liner plate fatigue analysis, and RPV neutron embrittlement. 
In fact, RPV embrittlement is an area that deserves consideration to assess the motivation to improve the technical basis for bench marking models to predict embrittlement. Several RPVs have already been assessed and found to meet criteria for operation for $60 \mathrm{y}$. Motivation for direct measurements of through-wall properties of RPVs arises if there are RPVs that may have marginal properties for 60y operation. If even one RPV can benefit from investigation of conservatisms in the models, a considerable investment in sampling and investigation of RPV specimens would be justified.

Aging in active equipment, such as valve and pump internals that has moving parts is managed under existing programs for surveillance, refurbishment, and replacement in current operation and in the period of LR. For example, pump and valve internals are considered active components. Aging management of some components is based on qualified life for a specified time frame. These components are not subject to aging management review under the Integrated Plant Assessment, 10 CFR 54.21(a)(1)(i, ii).

Through the year 2000, LRAs were evaluated for five PWR plants at two sites: the Baltimore Gas and Electric Calvert Cliffs (Units $1 \& 2$ ) and the Duke Power Oconee (Units 1, 2, \& 3). The safety evaluation report (SER) for Calvert Cliffs was published in 1999 (NRC 1999). The SER for Oconee was published in March 2000 (NRC 2000). In 2001, the NRC was evaluating LR requests for Arkansas Unit 1, a PWR, Catawba and McGuire PWRs, Turkey Point Units 3 and 4, PWRs, and Hatch Units $1 \&$ 2, BWRs. 


\subsection{Status of Shutdown NPPs in the U.S.}

Shutdown reactors offer opportunities to obtain a variety of CMSs that are generally not available from operating reactors, illustrated by the range of candidates that were accessed during the Shippingport NPP decommissioning, Section 7.2). Access to through-wall RPV specimens could only be obtained for a plant in shut-down status. An important consideration in shutdown plants is potential access to key locations important to aging assessments that are not accessible in operating plants, such as certain concrete structures. The list of U.S. reactors that are permanently shutdown is shown in Table $5.1^{1}$ (Hickey et al. 2001). Other information regarding the shutdown plants is available in Minns et al. 2000. Terminologies used in the table are explained as follows.

DECON: the equipment, structures, and portions of the facility and site that contain radioactive contaminants are removed or decontaminated to a level that permits termination of the license shortly after cessation of operations.

SAFSTOR: The facility is placed in a safe, stable condition and maintained in that state until it is decontaminated and dismantled to levels that permit license termination. During SAFSTOR, a facility is left intact, but the fuel has been removed from the reactor vessel, and radioactive liquids have been drained from the systems and components and then processed. Radioactive decay occurs during the SAFSTOR period, thus reducing the quantity of contaminated and radioactive material that must be disposed of during decontamination and dismantlement.

ENTOMB: A decommissioning method, not addressed in Table 5.1.

Information regarding the status of the plants is being generated, and staff on the NEPO project would remain current with the course of shutdown plant status to provide a basis for judgment regarding the practicality of accessing materials/equipment from the shutdown plants. Some of the plants are early vintage with equipment that has minimal relevance to many (perhaps not all) plants still in service. Some plants, such as Rancho Seco, had minimal service time. Several plants, including Millstone and the Zion units are largely intact (in SAFSTOR) and may offer valuable opportunities to obtain aging data, either from in situ investigations or by removal of materials/components for examination. However, post-service degradation of CMSs would need to be evaluated.

At some plants, major equipment has been removed. The Trojan reactor RPV and SGs have been transported from the site and buried. The possibility of obtaining cable samples from the Trojan reactor was investigated, but was not pursued. A major interest was shown in obtaining a section of the core shroud from the Maine Yankee reactor, but the window of availability closed before the effort to obtain the material could be implemented.

Not considered in Table 3.2 are production reactors at federal sites and test reactors at various locations that are in shutdown status. In general, the perception is that relevance of materials and operational histories are minimal to commercial NPPs. Whether concrete structures have relevance could be considered.

\footnotetext{
${ }^{1}$ The table indicates the status near the end of 2001. The table may not reflect the current status of all plants.
} 
Table 5.1. Permanently Shutdown Plants (Ref. Hickey et al. 2001)

\begin{tabular}{|c|c|c|c|c|c|c|c|}
\hline Nuclear Plant & Plant Type & $\begin{array}{l}\text { Thermal } \\
\text { Power }\end{array}$ & $\begin{array}{c}\text { Operating } \\
\text { License }\end{array}$ & Shut Down & $\begin{array}{l}\text { Decommissioning } \\
\text { Method }\end{array}$ & Location & $\begin{array}{l}\text { Fuel Status and License } \\
\text { Termination Date }\end{array}$ \\
\hline Big Rock Point & BWR & $240 \mathrm{MW}$ & $5 / 1 / 64$ & $8 / 29 / 97$ & DECON & Charlevoix, MI & Fuel onsite \\
\hline Dresden Unit 1 & BWR & $700 \mathrm{MW}$ & $9 / 28 / 59$ & $10 / 31 / 74$ & SAFSTOR & Morris, IL & Fuel onsite \\
\hline Fermi Unit 1 & Fast Breeder & $200 \mathrm{MW}$ & $5 / 1 / 63$ & $9 / 22 / 72$ & DECON & Monroe Co., MI & No fuel onsite \\
\hline Fort St. Vrain & HTGR & $842 \mathrm{MW}$ & $12 / 1 / 76$ & $8 / 18 / 89$ & DECON & Platteville, $\mathrm{CO}$ & $\begin{array}{l}\text { Fuel ISFSI / License terminated in } \\
1997\end{array}$ \\
\hline GE-VBWR & BWR & $50 \mathrm{MW}$ & $5 / 14 / 56$ & $12 / 9 / 63$ & SAFSTOR & Alameda Co., CA & No fuel onsite \\
\hline Haddam Neck & PWR & $1825 \mathrm{MW}$ & $12 / 27 / 74$ & $7 / 22 / 96$ & DECON & Haddam, CT & Fuel onsite \\
\hline Humboldt Bay Unit 3 & BWR & $200 \mathrm{MW}$ & $8 / 28 / 62$ & $7 / 2 / 76$ & Some D \& D & Eureka, CA & Fuel onsite \\
\hline Indian Point Unit 1 & PWR & $615 \mathrm{MW}$ & $3 / 26 / 62$ & $10 / 31 / 74$ & SAFSTOR & Buchanan, NY & Fuel onsite \\
\hline La Crosse & BWR & $165 \mathrm{MW}$ & $7 / 03 / 67$ & $4 / 30 / 87$ & SAFSTOR & LaCrosse, WI & Fuel onsite \\
\hline Maine Yankee & PWR & $2700 \mathrm{MW}$ & $6 / 29 / 73$ & $12 / 6 / 96$ & DECON & Wiscasset, ME & Fuel onsite \\
\hline Millstone Unit 1 & BWR & $2011 \mathrm{MW}$ & $10 / 7 / 70$ & $11 / 5 / 95$ & SAFSTOR & Waterford, CT & Fuel onsite \\
\hline Pathfinder & BWR & $190 \mathrm{MW}$ & $1 / 1 / 64$ & $9 / 16 / 67$ & SAFSTOR & Sioux Falls, SD & $\begin{array}{c}\text { No fuel onsite / License terminated in } \\
1992\end{array}$ \\
\hline Peach Bottom Unit 1 & HTGR & $115 \mathrm{MW}$ & $6 / 1 / 67$ & $10 / 31 / 74$ & SAFSTOR & York Co., PA & No fuel onsite \\
\hline Rancho Seco & PWR & $2772 \mathrm{MW}$ & $8 / 16 / 74$ & $6 / 7 / 89$ & SAFSTOR & Sacramento, CA & $\begin{array}{c}\text { Fuel onsite / partial DECON proposed } \\
\text { in } 1997\end{array}$ \\
\hline San Onofre Unit 1 & PWR & $1347 \mathrm{MW}$ & $3 / 27 / 67$ & $11 / 30 / 92$ & DECON & San Clemente, CA & Fuel onsite \\
\hline Saxton & PWR Test & $23 \mathrm{MW}$ & $11 / 15 / 61$ & $5 / 1 / 72$ & DECON? & Saxton, PA & No fuel onsite/ currently in DECON \\
\hline Shoreham & BWR & $2436 \mathrm{MW}$ & $6 / 1 / 85$ & $6 / 28 / 89$ & DECON & Suffolk County, NY & $\begin{array}{c}\text { No fuel onsite / License terminated in } \\
1995\end{array}$ \\
\hline Three Mile Island, Unit 2 & PWR & $2772 \mathrm{MW}$ & $2 / 8 / 78$ & $3 / 28 / 79$ & $\begin{array}{l}\text { Accident cleanup } \\
\text { followed by storage }\end{array}$ & Middletown, PA & $\begin{array}{l}\text { Approx } 900 \mathrm{~kg} \text { fuel onsite / Post- } \\
\text { Defueling Monitored Storage }\end{array}$ \\
\hline Trojan & PWR & $3411 \mathrm{MW}$ & $11 / 21 / 75$ & $11 / 9 / 92$ & DECON & Rainier, OR & Fuel onsite \\
\hline Yankee Rowe & PWR & $600 \mathrm{MW}$ & $12 / 24 / 63$ & $10 / 1 / 91$ & DECON & Rowe, MA & Fuel onsite \\
\hline Zion Unit 1 & PWR & $3250 \mathrm{MW}$ & $10 / 19 / 73$ & $2 / 21 / 97$ & SAFSTOR & Zion, IL & Fuel onsite \\
\hline Zion Unit 2 & PWR & $3250 \mathrm{MW}$ & $11 / 14 / 73$ & $9 / 19 / 96$ & SAFSTOR & Zion, IL & Fuel onsite \\
\hline
\end{tabular}




\subsection{Prospects to Obtain Materials/Components From Foreign Reactors}

A list of foreign reactors that are in shutdown status is available in Nuclear News, March 1999, p.55. A few LWR plants are on the list.

An incentive would arise if a key issue emerges during development of the plan that is not resolvable from candidates available in the U.S. An added attraction would accrue if investigation of one or more candidate materials/components from a foreign reactor were to attract multiple sponsors willing to share costs to resolve an issue that has broad application. 


\subsection{Major Programs Involving Examination of Naturally-Aged NPP Components}

Two programs illustrate the utilization of opportunities to investigate NPP components after substantial periods of reactor service: The Surry SG Project and the Shippingport Reactor Decommissioning Project are summarized in this section. The Surry SG project illustrates a major initiative that brought together the resources and technical capabilities of five sponsors to address aging issues in a major NPP component that has been troublesome across the PWR industry. The Shippingport initiative illustrates the practicality of accessing and examining a variety of aged NPP materials/components within the constraints of a decommissioning schedule and the exigencies of managing radioactive materials.

\subsection{Surry SG Project}

A degraded SG, removed from service in the Surry PWR (in Virginia) in the 1970s, was barged through the Panama Canal to the Hanford Nuclear Site in Washington State in May 1980. A multi-sponsor program was put in place to fund the investigations, involving NRC as the lead organization, EPRI, and consortia from France, Italy, and Japan. The Pacific Northwest National Laboratory ${ }^{1}$ (PNNL) was contracted to construct a special building to house the generator and to facilitate examination. Major aspects of the program included demonstration of decontamination of the channel head, correlation of nondestructive testing techniques with metallographic examination of specific defects, secondary side inspections using observation techniques, including fiber optics observations on corrosion in tube sheet crevices and characterization of the sludge pile. The term of the project was approximately five years, at a cost of $\$ 15$ million. A summary of the program and key results has been published (Kurtz et al. 1990).

\subsection{Shippingport Reactor Decommissioning}

The Shippingport Atomic Power Station was the first large-scale central-station U.S. NPP. The reactor operated for 25 years (1957 to 1982). Parts of the reactor had been upgraded, so available equipment spanned the range of equipment in the then-operating U.S. NPPs. Color photographs of potential candidates facilitated decisions for participants who had not had an opportunity to visit the plant. As the plant was being decommissioned, more than 200 items, ranging small instruments and materials samples to one of the main coolant pumps were removed and shipped to designated NRC contractors. The work to access and disperse the materials and components was managed for NRC by staff from PNNL. Seven other laboratories participated in examination of materials and equipment. Items included battery chargers, inverters, relays, breakers, switches, power and control cables, electrical penetrations, check valves, solenoid valves, and motor-operated valves. Samples of piping, valves, and the main coolant pump were collected for materials degradation studies.

Data and records were obtained and made available to relevant participants in the program. Two publications summarize the work to access and disperse the materials and components and reference some results from the examinations (Allen and Johnson 1990; Allen and Johnson 1990a).

\footnotetext{
${ }^{1}$ Pacific Northwest Laboratory (PNL) in the time frame of the project.
} 
The lessons learned in the Shippingport initiative need to be applied to future selection and examination of naturally aged materials and components from NPPs. Foremost is the need to conduct in advance a full and realistic estimate of all costs that will accrue from obtaining, examining, and disposing of a given material or component. If the candidate is even mildly radioactive, the receiving facility must have infrastructure and permits that allow examination and testing. Candidates with higher radiation levels or positioned in radiation zones may impose radiation doses to plant staff when the candidate is examined or tested in situ or is removed from its service location. The criteria provided in Section 4.1 reflect aspects of lessons learned in the Shippingport decommissioning initiative. 


\subsection{Ongoing Decommissioning Initiatives}

Two U.S. nuclear plants are in active decommissioning in 2001: Big Rock Point, a BWR located near Traverse City, Michigan and the San Onofre Nuclear Generating Station (SONGS) near San Clemente, California. Naturally aged materials are being obtained from both plants. The status of the decommissioning is summarized in this section.

\subsection{Big Rock Point - Status and Lessons Learned}

Project Summary

\section{EPRI-BWR Owners Group}

Big Rock Point Material Sampling Program

Frank E. Gregor, P.E.

LCM Technology, LC

\section{Overview}

The project was initiated under sponsorship of the BWR Owners Group and consisted of assembling an inventory of aged materials of potential interest. Availability and schedule for the decommissioning was then reviewed with the plant to minimize impact on the BRP plant. A decision was made to focus on Electrical Fuses (cartridge type), small and medium bore piping, belowground and underwater concrete and embedded containment shell samples. The fuses were the first to become available and some 100 were acquired and are in storage (at the LCM office). A test specification was written and reviewed, but testing was postponed.

The piping systems at BRP were reviewed to identify a limited set of representative samples, and the systems were inspected (walkdown) to select the desired locations and configurations. Samples were located, numbered and tagged. Next, the documentation at the plant was assessed to collect pertinent operating information (condition reports, ASME XI inspections, water chemistry records, plant cycles, decontamination data, etc).

While the decommissioning proceeds, the tagged samples are harvested and stored in a metal crate on the turbine floor. Some of the samples are highly radioactive $(\sim 500 \mathrm{mR} / \mathrm{h}$ contact) and some are toxic (PCB and lead paints). The current sample listing for the piping is attached.

Concrete samples will not become available until 2004 when the underground and underwater (intake pipe) concrete structures are demolished. One concrete sample from the reactor vessel shield wall has been secured as a result of core drilling to characterize the concrete contamination. The sample was also placed into the EPRI sample container. Sometime this year, additional concrete coring will take place to characterize the containment foundation. The plan calls for drilling through the containment bottom from 
the inside, such that the embedded shell will be penetrated. We will attempt to take digital photos of the concrete cores and the embedded shell surfaces to study and document the material condition.

Note: Interest in the fuses has been downgraded.

\section{Current Situation}

During 2003, the buildings at the site are scheduled for demolition, such that continued storage of the radioactive samples is no longer feasible. Funding for the testing of the piping materials in 2002 has not materialized. The candidates will be likely be returned to the BRP waste stream for disposal during 2002 to avoid future liabilities.

\section{Lessons Learned from the BRP Project}

- Successful retrieval of aged materials requires very long term planning. The decommissioning schedule stretches over 7 to 10 years.

- Acquisition of associated design, operating and maintenance records needs to commence early and before the material is lost or damaged.

- The decontamination processes used may interfere with the desire to harvest unadulterated samples.

- Identifying, tagging, and tracking samples over a long period to assure preservation of identity requires considerable attention.

- Project objectives and needs change over time

- Some early opportunities to secure CASS material (pump and valve bodies) and reactor vessel internals were missed because of lack of funding and lack of national interest.

- Digital photography is extremely helpful in preserving the original sample location and configuration and documenting initial surface conditions. We also used VT inspection forms to record the sample conditions once harvested (external and internal appearance).

- On a decommissioning site, personnel changes frequently, and continued site presence/interaction is necessary to assure that project objectives are maintained.

\subsection{San Onofre Nuclear Generating Station Unit 1 (SONGS-1)}

Decommissioning of the SONGS-1 PWR began in June 1999, and the first phase is projected to be completed in 2008. The first phase includes the removal of all above grade structures, most of the foundations, and the construction and loading of SONGS 1 fuel in the Independent Spent Fuel Storage Installation (ISFSI). Phase II will involve monitoring of the fuel in the ISFSI until the DOE fulfills its obligation to remove the fuel from the site, and Phase II will involve completion of the decommissioning by removing all remaining foundations and the ISFSI. Interest has been indicated in obtaining specimens from the reactor internals and possibly, the RPV. However, cutting a specimen from the RPV is not practical because it was not known before the reactor vessel internal components segregation project began. In addition, other large components will all be shipped intact (i.e., will not be segregated). However, several specimens were removed from the reactor internals components and have been shipped to Westinghouse, including the following: 
- $\quad$ Specimens from baffle plate, $304 \mathrm{SS}, 4-30 \mathrm{dpa}$, from core midplane $<1 \mathrm{E}+20 \mathrm{n} / \mathrm{cm}^{2}$

- Former plate specimens, $304 \mathrm{SS}, 4-30 \mathrm{dpa}$, from core midplane, highest fluence

- Specimens from baffle-former bolt shanks, $304 \mathrm{SS}, 4-15$ dpa, core midplane, highest fluence

- Core barrel specimens, $304 \mathrm{SS}, 0.5-4$ dpa, weld nearest core midplane, highest fluence.

SONGS has expressed interest in contributing to the NEPO Program, provided that the identification and planning are conducted in sufficient time to prevent conflicts in the overall decommissioning project schedule. Other targets of opportunity still seem feasible in the time frame of the decommissioning, for example, examination of concrete in inaccessible locations, underground piping and tanks, and possibly other CMSs if the candidates are judged to have sufficient justification and if the windows of opportunity do not close before planning and funding could be arranged. 


\subsection{Review of Aging/License Renewal Initiatives and Literature}

This review provides perspectives regarding the scopes of current aging and LR studies and provided guidance to the NEPO project on selection of naturally aged NPP equipment for investigation. The intent of the review is to provide perspective rather than details.

\subsection{Electric Power Research Institute Initiatives}

The EPRI is the technical arm of the U.S. electrical power industry. The institute is committed to reducing operating costs and improving plant reliability, and, relevant to the NEPO Program, to maintaining/improving safety margins. Studies relevant to commitments include development of technology to improve management of SG degradation issues, such as tube denting, tube corrosion, and fouling. Other major initiatives to counter aging include development of remedial measures for BWR pipe cracking and reactor vessel embrittlement. EPRI operates a non-destructive evaluation (NDE) facility that addresses the NDE needs of individual plants and advances the state-of-the-art in NDE technology. The EPRI 1999-2000 Materials Research Program (MRP) identified 15 projects. The BWR Vessel and Internals Project (BWRRVIP), the Corrosion Research group, the NDE Strategic Initiatives Program, the NDE Technology Development group, and the Instrument and Control group decide which EPRI initiatives should be conducted to address NPP aging.

The Cooperative Industry Research (CIR) program is managed by EPRI to develop a mechanistic understanding of irradiation-assisted stress corrosion cracking (IASCC), including a methodology for predicting component behavior and developing countermeasures that mitigate IASCC. The program includes investigation of the effects of materials susceptibility, water chemistry, and stress, using materials from other programs to conduct controlled experiments in hot cells and test reactors.

The Reactor Internals-ITG provides oversight for management of material aging effects on PWR RV internals. The ITG is sponsored by EPRI; it involves combining programs and commitments from owners groups (OG), utilities, and international organizations. The ITG is developing a strategic plan for assessing and managing potential aging degradation effects in PWR vessel internals.

The EPRI program on SGs focuses on improved methods of characterizing the current condition of installed SGs and of predicting and controlling their future rate of degradation.

The EPRI program on aging of NPP cables and assessment of their condition includes a natural vs. an artificial aging project and ion gas testing research. A report, TR-106108, "Diagnostic Evaluation of Low-Voltage Electrical Cables" provides an overview of condition assessment technologies and indicates relevant tests for pre-service and in-service inspections, aging assessments, troubleshooting, and failure assessment of cables.

EPRI is supporting RPV annealing demonstrations to significantly extend operating lifetimes for PWR plants. EPRI is collaborating with CRIEPI (a Japanese nuclear energy consortium) to support fundamental studies of radiation embrittlement of RPV steel. Prompted by difficulties in applying 
available methods to analyze the Yankee Rowe RPV outlined in NRC Regulatory Guide 1.154, EPRI has developed an alternate approach to evaluate pressurized thermal shock (PTS). Work is underway to demonstrate and gain acceptance for this approach.

An EPRI project involves development of a materials handbook for NPP pressure boundary applications. The handbook is to be used as the primary source document to guide repairs, replacement materials, troubleshooting failures, failure analysis, and in-service inspections. EPRI is also providing guidance on the useful service life of valve stem and bolting alloys that are susceptible to thermal embrittlement, prompted by service failures from embrittlement of PWR components, and perhaps failures involving stress corrosion cracking.

Investigations of NPP aging, jointly funded by DOE and EPRI under the NEPO program, are reviewed in Section 9.5.

\subsection{International Atomic Energy Agency (IAEA) Initiatives}

To increase awareness of aging issues, the IAEA, with headquarters in Vienna, Austria, initiated activities in 1985 regarding the safety aspects of NPP aging. In 1989, a systematic project was started to help member states understand that aging of the SCC is important to safety and to develop effective aging management strategies. In a third phase, development and document preparation has provided component-specific guidelines for six materials/components relevant to LWR. The IAEA guidelines address the following components/structures:

Steam Generators (IAEA 1997)

Concrete Containment Buildings (IAEA 1998)

PWR Pressure Vessels (IAEA 1999)

PWR Vessel Internals (IAEA 1999a)

Metal Components of BWR Containment Systems (IAEA 2000)

In-Containment Instrumentation and Control Cables (IAEA 2000a).

\subsection{Japanese Initiatives}

In Japan, no code exists to regulate the plant life of NPPs. Permission to operate is granted for each operating cycle, on the condition that integrity of components is confirmed by authorized inspection (Murano 2000). Consequently, LR for a fixed period, for instance 20 years, is not consistent with the Japanese approach to licensing. Nevertheless, a comprehensive program in Japan investigates the viability of NPP operation for up to 60 years.

The Japanese light water industry is conducting an industry-wide program entitled "Plant Life Management for Nuclear Power Plants." Three plants have been chosen as representatives for full evaluation. They are Tsuruga-1, a BWR operated by JAPCO, Mihama-1, a PWR operated by KEPCO, and Fukushima 1-1, a BWR operated by TEPCO.

Identification of the aging phenomena starts with all systems and structural components throughout the plant. Those components not safety-related are subject to the usual inspection. Those identified as easy 
to repair or replace are subject to repair/replacement as necessary. Those structures/components for aging evaluation comprise the following: BWR- 6 Components, 1 Structure; PWR- 8 Components, 1 Structure. The PWR components/structures are:
Reactor Vessel
Reactor Internals
Main Coolant Pipe
Reactor Coolant Pump
Pressurizer
Steam Generator
Electrical Cable
Containment Vessel
Concrete Structures

The BWR list is not currently available.

The comprehensive aging evaluations are conducted after about 30 years from the start of commercial operation. The evaluations address expected integrity in 60 years of operation. Current maintenance practices are evaluated and future technological development needs are identified.

Further NPP age-related initiatives in Japan include the following (IAEA 1999a):

- Nuclear Plant Rejuvenation Reliability Test Program, being conducted by Nuclear Power Engineering Corporation (NUPEC), to demonstrate the reliability of reactor vessel internal replacement by conducting mock up tests in full-scale test facilities.

- Repair welding technology of irradiated materials (WIM), conducted by Japan Power Engineering Corporation (JAPEIC), to develop repair welding technology for neutron irradiated core internals, such as baffle plates, core barrels and radial support, and reactor vessels.

\subsection{Other International Programs to Investigate Aging Issues}

Several international conferences have addressed aging and aging management in NPPs. All countries with NPP programs have been represented at the conferences, sharing information regarding the aging issues and how they have been approached in the respective plants. To illustrate, a conference held in Prague provided a broad perspective of plant life management and plant life extension (PLIM + PLEX 1997).

In France, EDF, CEA, and Framatome are conducting a program to study the behavior of reactor internals after severe irradiation conditions [up to 80 displacements per atom (dpa) at $328^{\circ} \mathrm{C}$ ]. The irradiation is conducted in the BOR 60 reactor in Russia (IAEA 1999a).

A joint Japanese and Russian program is underway to study structural materials of the VVER reactor vessel internals, including investigation of 18/10 austenitic material behavior, visual inspection and measurements on internal materials at one VVER-1000 plant, development of 2D and 3D stress-strain 
analyses, determination of fatigue strength and brittle fracture strength, and revision of neutron flux analysis procedures (IAEA 1999a).

These specific citations are indicative that NPP aging studies are underway in other countries, in these cases, benefiting from cooperative research.

\subsection{U.S. Department of Energy Initiatives}

DOE has sponsored research to support aging and license renewal initiatives, at first under DOE sponsorship. A Memorandum of Understanding (MOU) between DOE and EPRI was signed in 1986 and was updated in 1991. The MOU expired in 1995 and was replaced with the DOE/EPRI Sustainable Electric Partnership Agreement. The following initiatives are being implemented under the DOE/EPRI industry programs for commercial LWR:

Reactor Pressure Vessel Annealing

Cable Life Assessment and Condition Monitoring

Instrumentation and Control (I\&C) Upgrade

System, Structure, and Component Aging Evaluations

Codes and Standards and Regulatory Process Development

The Nuclear Energy Institute (NEI) also is involved in the initiatives.

In cooperation with EPRI, DOE participated in completion of 10 Industry Reports that were submitted to NRC:

BWR Primary Containment

BWR Primary Coolant Pressure Boundary

BWR Reactor Pressure Vessel

BWR Reactor Pressure Vessel Internals

PWR Containment

PWR Reactor Coolant System

PWR Reactor Pressure Vessel

PWR Reactor Pressure Vessel Internals

Class I Structures

Low Voltage Environmentally Qualified Cables.

DOE also participated in publication of several aging management guidelines.

In 1996, DOE and the industry undertook a formal review of nuclear energy R\&D needs. The NEPO cooperative and cost-shared plan is based on a joint DOE-EPRI plan first issued in 1998 (DOE-EPRI 1998) and updated in 2000 A.D.

The NEPO plan acknowledges the significance of materials degradation on the viability of NPPs, in some cases causing premature shutdown before the end of the 40 -year license period. The cost of replacing 
degraded SGs caused premature shutdown of the Trojan reactor in Oregon. Difficulties in resolving issues relating to reactor pressure vessel (RPV) embrittlement strongly influenced the decision to shut down the Yankee Rowe reactor in Massachusetts.

Material degradation management for operating NPP requires the ability to assess the condition of the materials, providing a basis to determine the operability of structures and components. Methods have been developed and, in many cases codified, to characterize the material condition. For some materials, nondestructive methods are not applicable. For example, NDE has not been developed to directly assess the degree of RPV embrittlement. Instead, the determination of degree of embrittlement relies on empirical correlations that can be very conservative when applied to specific plants. Assessments that are overly conservative may bias decisions regarding the prospects for a plant to gain license renewal. Determination of the condition of SG tube degradation is based on NDE methods that are sometimes only partially effective in detecting and sizing defects. When defects cannot be determined as safe, specific tubes must be taken out of service by plugging or by repair, such as sleeving.

The NEPO plan indicates a need to understand, characterize, and manage service-induced degradation of RPVs, reactor internals, SG tubes, reactor coolant system piping, electrical cables, and safety-related structures. Technology is needed for timely detection, mitigation, and prevention of long-term effects of aging, such as stress corrosion cracking, IASCC, neutron-induced reduction of fracture toughness, thermal embrittlement of cast SS, piping fatigue, and structural degradation. The proposed multi-year program needs to involve laboratory tests, component inspections, and technology demonstrations. The proposed NEPO plan involves the element of material/component examinations.

The DOE nuclear focus has included funding of Nuclear Energy Research Initiatives (NERI) to help overcome the principal technical and scientific issues affecting future use of nuclear energy in the U.S. (See http://neri.ne.doe.gov/overview00.html. Current (2001) NERI projects that address aging issues in NPP include the following:

Application of Innovative Experimental and Numerical Techniques for the Assessment of Reactor Pressure Vessel Structural Integrity

Investigation of the Mechanism of IGA/SCC of Alloy 600 in Corrosion Accelerating Heated Crevice Environments

Radiation-Induced Chemistry in High Temperature and Pressure Water and its Role in Corrosion.

Novel Investigations of Iron Cross Sections via Spherical Shell Transmission Measurements and Particle Transport Calculations for Material Embrittlement Studies

On-line Intelligent Self-Diagnostic Monitoring for Next Generation NPPs. 


\subsection{U.S. Nuclear Regulatory Commission Initiatives}

The U.S. NRC has sponsored research in several areas that are relevant to aging management in NPPs. The Nuclear Plant Aging Research (NPAR) Program was conducted through most of the 1980s (starting in 1982) and early 1990s (NRC 1991). The NPAR program involved aging assessments on 19 NPP safety systems and 26 safety-related components.) Specific goals of the program were: (1) To identify and characterize aging and service wear effects that, if unchecked, could cause degradation of systems, structures, and components (SSCs) and thereby impair plant safety; (2) To identify methods of inspection, surveillance and monitoring, for evaluating residual life of SSCs that assure timely detection of significant aging effects prior to loss of the safety function, and (3) To evaluate the effectiveness of storage, maintenance, and repair and replacement practices in mitigating the rate and extent of degradation caused by aging and service wear.

Documentation of the NPAR studies is provided in an NRC report (NRC 1992) and includes summaries of reports that address aging assessments of individual systems and components.

The NRC program on SGs emphasizes the assessment of current and emerging NDE technology and assessment of tube integrity. The lead laboratory for NRC investigations of SG aging is Argonne National Laboratory. The Surry SG project involved a multi-sponsor 5-year program to investigate a degraded SG. The NRC was the lead sponsor of the project (see Section 7.1).

The NRC is sponsoring fundamental studies on embrittlement of RPV steel at University of California, Santa Barbara, and at the Oak Ridge National Laboratory.

A major NRC initiative has involved development of the Generic Aging Lessons Learned (GALL) report NUREG/CR-6490). The report is a systematic compilation of plant aging information. The report provides analysis of safety-related components, including identification of materials, environments, aging effects, aging mechanisms, and relevant aging management programs, and refers to the sources for the aging management evaluation and technical basis.

The GALL report provides considerable guidance regarding aging management areas that require ongoing assessment. Review of the issues identified may provide useful guidance to selection of materials/components for examination.

Another ongoing NRC initiative potentially relevant to age-related evaluations is the list of generic safety issues, provided in NUREG-0933, A Prioritization of Generic Safety Issues. The status of resolution of the issues needs assessment for possible relevance to the NEPO project.

A recent study sponsored by NRC includes prioritization of structures/components for further evaluation (Braverman 2000). The structures/components are ranked according to the following considerations: seismic risk significance, degradation occurrences, importance to current licensing basis/LR, adequacy or existing programs, and ranking for further study. These considerations will be reviewed for possible relevance to selection of naturally aged materials/components under this NEPO program. 


\subsection{Nuclear Plant Owner Group Studies}

In the U.S., four LWR designs are in service: Babcock and Wilcox (PWR), Combustion Engineering (PWR), General Electric (BWR), and Westinghouse (PWR). Operators of each reactor type have developed owners groups (OGs) that focus on issues specific to the respective LWR types. The OGs have been active in developing understanding and management of aging and in preparing to move forward with license renewal. To cite an example, the B \& W OG Generic License Renewal Program, BAW-2279P, issued a report, Aging Effects for Structures and Structural Components (Structural Tools). 


\subsection{Conclusions}

1. As operating periods of nuclear plants increase, there is a sustained need for selective access to naturally aged CMSs to confirm satisfactory durability, look for evidence of new aging phenomena, and to validate the margins that were originally designed into the plants. Examples of recent degradation of materials involve a nozzle failure at the V.C. Summer PWR and CRDM failures at several PWRs. Further benchmarking of radiation effects on RPV embrittlement is an example of a need for margin validation.

2. This project, sponsored by NEPO, is based on the premise of a need for a systematic, ordered approach to identify and access naturally aged CMSs to facilitate timely identification of candidates; to assure that a given candidate will effectively resolve an aging issue; to assure that requisite background information on the candidate will be available; and to provide realistic cost estimates for access, investigation, and disposal of a candidate. A systematic approach will also mitigate the problem of investing resources in accessing CMSs that turn out to have marginal value, resulting in disposal without investigation.

3. The primary list of naturally aged candidates has the following entries: RPV vessel walls and nozzles, SG tubes and shells, concrete structures (other than containments), BWR and PWR vessel internals, thermally aged CASS pipe, buried piping and tanks, and flat bottomed tanks. Perspectives on the motivation for selection are provided. The list is preliminary, subject to broader review and comment. The list will also change with time as aging issues are resolved or as new issues emerge. A list of secondary candidates was developed to accommodate differences of opinion regarding candidates that deserve consideration.

4. A matrix approach to analyze status and issues for a given aged component was designed by a steering committee of staff from DOE, EPRI, and PNNL and was applied to the primary components.

5. Summaries of lessons learned from prior or ongoing NPP decommissionings are provided to guide future initiatives.

6. An example, the Surry Stream Generator Project, is cited as a multi-sponsor initiative that may serve as a model for large, expensive projects, such as sampling RPV vessel walls.

7. A list of shutdown U.S. NPPs is provided as guidance to possible sources of CMSs.

8. A brief review of domestic and foreign aging studies is provided, conducted to assess the leading CMSs that have had major attention in NPP aging assessments. 


\subsection{References}

Allen, R. P., and A. B. Johnson, Jr. 1990. Shippingport Station Aging Evaluation Final Report, NUREG/CR-5491, PNL-7191. Prepared for the U.S. Nuclear Regulatory Commission by Pacific Northwest Laboratory, Richland, Washington.

Allen, R. P., and A. B. Johnson, Jr. 1990a. "Lessons Learned to Date from the Shippingport Aging Evaluation." Nucl. Eng. and Design, Vol. 118, pp. 319-327.

Braverman, J. I., C. H. Hofmaher, R. J. Morante, S. Shteyngart, P. Bezler. 2000. Assessment of AgeRelated Degradation of Structures and Passive Components for U.S. Nuclear Power Plants, NUREG/CR6679, BNL-NUREG-52587. Prepared for the U.S. Nuclear Regulatory Commission (NRC) by Brookhaven National Laboratory, Upton, New York

Davies, L.M., 1997, "A Comparison of Western and Eastern Nuclear Reactor Pressure Vessel Steels," Ames Report No. 10, Published by the EUROPEAN COMMISSION, LUXEMBOURG.

DOE-EPRI. 1998. Joint DOE-EPRI Strategic Research and Development Plan to Optimize U.S. Nuclear Power Plant. US Department of Energy, Germantown, Maryland. Electric Power Research Institute, Palo Alto, California (1998).

Garner, F. A., and M. B. Toloczko. 1997. "Irradiation Creep and Void Swelling of Austenitic Stainless Steels at Low Displacement Rates in Light Water Energy Systems", J. of Nucl. Mater. 251, 252-261.

Hickey, E. E., R. Harty, N. Durbin (PNNL), and P.W. Harris (NRC). 2001. Resident Inspector Handbook, NUREG/BR-0279. Prepared for U.S. Nuclear Regulatory Commission (NRC) by Pacific Northwest National Laboratory, Richland, Washington.

International Atomic Energy Agency (IAEA). 1997. Assessment and Management of Ageing of Major Nuclear Power Plant Components Important to Safety: Steam Generators, IAEA-TECDOC-981. IAEA, Vienna, Austria.

International Atomic Energy Agency (IAEA). 1998. Assessment and Management of Ageing of Major Nuclear Power Plant Components Important to Safety: Concrete Containment Buildings, IAEATECDOC-1025, IAEA, Vienna, Austria.

International Atomic Energy Agency (IAEA). 1999. Assessment and Management of Ageing of Major Nuclear Power Plant Components Important to Safety: PWR Pressure Vessels. IAEA-TECDOC-1120. IAEA, Vienna, Austria. 
International Atomic Energy Agency (IAEA). 1999a. Assessment and Management of Ageing of Major Nuclear Power Plant Components Important to Safety: PWR Vessel Internals, IAEA-TECDOC-1119. IAEA, Vienna, Austria.

International Atomic Energy Agency (IAEA). 2000. Assessment and Management of Ageing of Major Nuclear Power Plant Components Important to Safety: Metal Components of BWR Containment Systems . IAEA-TECDOC-1181. IAEA, Vienna, Austria.

International Atomic Energy Agency (IAEA). 2000a. Assessment and Management of Ageing of Major Nuclear Power Plant Components Important to Safety: In-containment Instrumentation and Control Cables. IAEA-TECDOC-1188. IAEA, Vienna, Austria.

Kurtz, R. J., et al. 1990. Steam Generator Integrated Program/Stream Generator Group Project, Final Project Summary Report, NUREG/CR-5117, PNL-6226. Prepared for the U.S. Nuclear Regulatory Commission (NRC) by Pacific Northwest Laboratory, Richland, Washington.

Minns, J. L., M. T. Masnik (NRC), R. Harty, and E. E. Hickey. 2000. Staff Responses to Frequently Asked Questions Concerning Decommissioning of Nuclear Power Reactors. NUREG-1628. U.S. Nuclear Regulatory Commission (NRC), Washington, D.C. Prepared for the U.S. Nuclear Regulatory Commission, by Pacific Northwest National Laboratory, Richland, Washington.

Murano, K. 2000. “Japan's Approach to Plant Life Extension,” Nucl. Plant J., Vol. 18, No. 5.

PLIM + PLEX 97. 1997. Plant Life Management and Plant Life Extension in Nuclear Facilities." Conference Proceedings, Prague, Czech Republic, 8-10 December. Published by Nuclear Engineering International, Wilmington Business Publishing, Kent, United Kingdom.

U.S. Department of Energy-Electric Power Research Institute (DOE-EPRI). 1998. Joint DOE-EPRI Strategic Research and Development Plan to Optimize U.S. Nuclear Power Plant. U.S. Department of Energy, Germantown, Maryland. Electric Power Research Institute, Palo Alto, California.

U.S. Nuclear Regulatory Commission (NRC). 1991. Nuclear Plant Aging Research (NPAR) Program Plan, NUREG-1144, Rev 2, (1991). U.S. Nuclear Regulatory Commission, Rockville, Maryland.

U.S. Nuclear Regulatory Commission (NRC). 1992. Research Program on Plant Aging: Listing and Summaries of Reports Issued Through July 1992. NUREG-1377.

U.S. Nuclear Regulatory Commission (NRC). 1999. Safety Evaluation Report for Calvert Cliffs Nuclear Power Plant, Units 1 and 2. NUREG-1705. Division of Regulatory Improvement, NRR, U.S. NRC. Washington D.C. 
U.S. Nuclear Regulatory Commission (NRC). 2000. Safety Evaluation Report for Oconee Nuclear Station, Units 1 and 2, NUREG-1723. March 2000. Division of Regulatory Improvement, NRR, U.S. NRC, Washington D.C.

U.S. Nuclear Regulatory Commission (NRC), 1995, Assessment of In service Condition of Safety-Related Nuclear Plant Structures, NUREG-1522, U.S. Nuclear Regulatory Commission, Rockville, Maryland.

U.S. Nuclear Regulatory Commission (NRC), 2001, Generic Aging Lessons Learned (GALL) Report, NUREG-1801, U.S. Nuclear Regulatory Commission, Rockville, Maryland.

U.S. Nuclear Regulatory Commission (NRC) 2001a, NRC RESEARCH AREAS FOR FISCAL YEAR 2001, http://www.nrc.gov/RES/resproj.htm, U.S. Nuclear Regulatory Commission, Rockville, Maryland. 